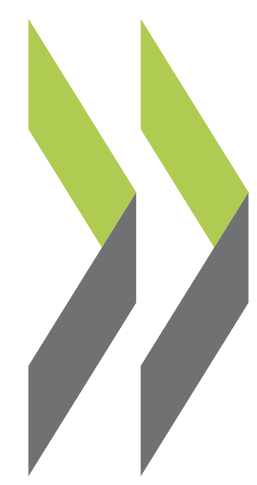

OECD Science, Technology and Industry Working Papers $2005 / 02$

\title{
Impact of Patent Co- Operation Treaty Data on Epo Patent Statistics and Improving \\ the Timeliness of EPO Indicators
} Mosahid Khan, Hélène Dernis 
Organisation de Coopération et de Développement Economiques

Organisation for Economic Co-operation and Development

09-Feb-2005

DIRECTORATE FOR SCIENCE, TECHNOLOGY AND INDUSTRY

English text only

IMPACT OF PATENT COOPERATION TREATY DATA ON EPO PATENT STATISTICS AND IMPROVING THE TIMELINESS OF EPO INDICATORS

STI WORKING PAPER 2005/2

Statistical Analysis of Science, Technology and Industry

Mosahid Khan and Hélène Dernis 


\section{STI Working Paper Series}

The Working Paper series of the OECD Directorate for Science, Technology and Industry is designed to make available to a wider readership selected studies prepared by staff in the Directorate or by outside consultants working on OECD projects. The papers included in the series cover a broad range of issues, of both a technical and policy-analytical nature, in the areas of work of the DSTI. The Working Papers are generally available only in their original language - English or French - with a summary in the other.

Comments on the papers are invited, and should be sent to the Directorate for Science, Technology and Industry, OECD, 2 rue André-Pascal, 75775 Paris Cedex 16, France.

The opinions expressed in these papers are the sole responsibility of the author(s) and do not necessarily reflect those of the OECD or of the governments of its member countries.

\section{http://www.oecd.org/sti/working-papers}




\title{
IMPACT OF PATENT CO-OPERATION TREATY DATA ON EPO PATENT STATISTICS AND IMPROVING THE TIMELINESS OF EPO INDICATORS
}

\author{
Mosahid Khan and Hélène Dernis
}

\begin{abstract}
The Patent Cooperation Treaty provides the possibility to seek patent rights in a large number of countries by filing a single international application with a single patent office. Since the mid-1980s, the patent cooperation treaty (PCT) procedure has become a popular method for filing patent applications, as is reflected in the substantial increase in PCT applications over the past 15 years.

This paper analyses the impact of the PCT data on the European Patent Office (EPO) patent statistics, and explores methods to improve the timeliness of the EPO indicators by estimating the number of PCT applications which enter the EPO regional phase (see Annex A for details). This paper shows the following main impacts of PCT data in the EPO patent statistics:

- Including all EPO designated PCT applications data will overestimate the total number of EPO patent applications; and

- It will introduce a bias in favour of non-EPC countries (countries that are not signatory to the European Patent Convention). That is to say, the overestimation of the total number of EPO patent applications for non-EPC countries will be higher than the overestimation for the EPC countries.

Nevertheless, analyses show that inclusion of PCT data in the EPO patent statistics is essential for an accurate measure of the total number of EPO patent applications. It is therefore suggested that only the PCT applications which enter the EPO regional phase should be included in EPO patent statistics because:

- $\quad$ PCT applications which enter the EPO regional phase account for more than half of total EPO patent applications.

- The grant rate of PCT applications which enter the EPO regional phase is comparable to the grant rate of direct EPO applications (i.e. applications filed without the PCT procedure). This will improve the comparability of EPO patent statistics.

- Restricting only to the PCT applications which enter the EPO regional phase will limit the overestimation of the total number of EPO patent applications.

A major drawback of including only the PCT applications which enter the EPO regional phase is that it will adversely affect the timeliness of EPO patent indicators. It may take up to 31 months from the priority date (i.e. the date of first filing of a patent application anywhere in the world) for EPO designated PCT applications to enter the EPO regional phase. Taking other administrative delays into consideration, it could take around 36 months before the information becomes publicly available. However, this paper shows that it is possible to improve the timeliness of the EPO patent indicators by estimating the number of EPO regional phase PCT applications.
\end{abstract}




\title{
RÉPERCUSSIONS DU TRAITÉ DE COOPÉRATION EN MATIÈRE DE BREVETS SUR LES STATISTIQUES DES BREVETS DE L'OEB ET POSSIBILITÉS D'AMÉLIORATION DE CES INDICATEURS
}

\author{
Mosahid Khan et Hélène Dernis
}

\section{Résumé}

Le Traité de coopération en matière de brevets permet, en déposant une seule demande internationale de brevet, d'obtenir la protection d'une invention conférée par un brevet dans un grand nombre de pays. Depuis le milieu des années 80 , la procédure en vertu du traité de coopération en matière de brevets (PCT) connaît un succès grandissant, ainsi qu'en témoigne l'augmentation considérable du nombre de demandes PCT au cours des 15 dernières années.

Le présent document analyse les répercussions des données du PCT sur les statistiques de l'Office européen des brevets (OEB) et étudie les possibilités d'améliorer la disponibilité de ces indicateurs pour les années récentes en effectuant des estimations du nombre de demandes PCT entrant dans la phase régionale de l'OEB (voir l'Annexe A pour plus de détails). Le présent document met en évidence les répercussions principales suivantes :

- Si l'on inclut les données relatives à la totalité des demandes PCT désignant l'OEB, cela aura pour conséquence de fausser à la hausse le nombre total des demandes de brevets déposées auprès de l'OEB ; et

- Les données du PCT infléchiront les résultats en faveur des États non contractants (pays qui n'ont pas signé la Convention sur le brevet européen). Cela signifie que le nombre total des demandes de brevets déposées auprès de l'OEB pour les pays non signataires de la Convention sur le brevet européen sera surestimé par rapport au total relatif aux pays signataires.

Toutefois, les analyses révèlent qu'il est nécessaire d'intégrer les données du PCT dans les statistiques des brevets de l'OEB afin de mesurer avec exactitude le nombre total des demandes de brevets déposées auprès de l'OEB. Il est par conséquent proposé de n'inclure dans les statistiques des brevets de l'OEB que les demandes PCT qui entrent dans la phase régionale de l'OEB, et ce pour les raisons suivantes :

- Les demandes PCT entrant dans la phase régionale de l'OEB représentent plus de la moitié de la totalité des demandes de brevets déposées auprès de l'OEB.

- Le taux de délivrance des demandes PCT entrant dans la phase régionale de l'OEB est comparable à celui des demandes effectuées directement auprès de l'OEB (c'est-à-dire les demandes ne suivant pas la procédure en vertu du PCT). Cela permettra d'améliorer la comparabilité des statistiques des brevets de l'OEB.

- Se limiter aux demandes PCT entrant dans la phase régionale de l'OEB limitera la surestimation du nombre total des demandes de brevets déposées auprès de l'OEB.

Inclure uniquement les demandes PCT entrant dans la phase régionale de l'OEB présente toutefois un inconvénient majeur, celui de diminuer la disponibilité des statistiques des brevets de l'OEB pour les années récentes. En effet, il peut s'écouler jusqu'à 31 mois entre la date de priorité (c'est-à-dire la date du dépôt de brevet initial dans n'importe quel pays du monde) et l'entrée des demandes PCT désignant l'OEB dans la phase régionale de l'OEB. Si l'on tient compte du temps nécessaire pour effectuer les autres formalités administratives, la publication de l'information pourrait prendre environ 36 mois. Le présent document démontre toutefois qu'il est possible d'améliorer la disponibilité des indicateurs de brevets de l'OEB pour les années récentes en effectuant des estimations du nombre des demandes PCT entrant dans la phase régionale de l'OEB. 
TABLE OF CONTENTS

1. Introduction $\quad 6$

$\begin{array}{ll}\text { 2. } & \text { Patenting procedures }\end{array}$

3. $\quad$ PCT and EPO patent applications $\quad 8$

4. Impact of PCT applications on EPO data 10

5. Methods for nowcasting EPO data 14

$\begin{array}{ll}\text { 6. Nowcasting results } & 18\end{array}$

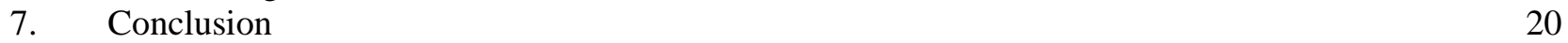

ANNEX A: THE PATENT COOPERATION TREATY (PCT) 22

International phase $\quad 22$

National/regional phase $\quad 24$

Main advantages of the PCT procedure $\quad 25$

$\begin{array}{ll}\text { ANNEX TABLES } & 27\end{array}$

REFERENCES 36 


\section{Introduction}

Patents are intellectual property rights issued by authorised bodies to inventors to make use of and exploit their inventions for a limited period of time. They are granted by a national or regional patent office (e.g. the European Patent Office, EPO) and the rights are limited to the territory covered by the patent office. It is possible to seek patent rights in many national and/or foreign territories. The decision on where to seek patent rights is determined by the patenting strategy of the applicants. Generally, applicants first tend to seek patent rights within their domestic territory and subsequently within foreign territories.

Patent indicators are a key measure of innovative output, as they are one reflection of the inventive performance of countries, regions, technologies, etc. They are also used to measure the diffusion of ideas and the level of internationalisation and international collaboration across countries (OECD, 2004). Patent indicators are calculated according to domestic and/or foreign patent filings to a national or a regional patent office. The type of data taken into consideration (e.g. which patent office, type of filings, or the procedure used to file patent applications) has a significant influence on the derived patent indicators.

The objectives of this paper are twofold: $a$ ) to analyse the impact of Patent Cooperation Treaty data on EPO patent statistics and to recommend whether or not to include Patent Cooperation Treaty (PCT) data in EPO patent statistics; and $b$ ) to improve the timelines of EPO patent statistics by "nowcasting" (i.e. forecasting the recent past) the number of PCT applications which enter the EPO regional phase.

\section{2. $\quad$ Patenting procedures}

Understanding the procedures that are used to file patent applications at the European Patent Office is the key to interpreting patent statistics in an accurate manner. Patent applications at the EPO can be filed using the European Patent Convention (EPC) or the Patent Cooperation Treaty (PCT) procedures.

- The European Patent Convention (EPC) led to the creation of the European Patent Office (EPO) that grants European Patents ${ }^{1}$ based on a centralised examination procedure. By filing a single European patent application in one of the three official languages (English, French and German), it is possible to obtain patent rights in all EPC countries. Patents granted by the EPO have the same legal rights and are subject to the same conditions as national patents (i.e. those granted by national patent offices) in each EPC country for which the patent has been granted.

- The Patent Cooperation Treaty (see Annex A for a detailed explanation) provides the possibility to seek patent rights in a large number of countries by filing a single international application (PCT application) with a single patent office (the receiving office). However, it should be noted that PCT applications do not result in the issuance of "international patents". The decision on whether to grant or reject patent rights rests with national or regional patent offices; they are limited to the territory under the governing authority's jurisdiction. The PCT procedure consists of two main phases: $a$ ) an international phase; and $b$ ) a PCT national/regional phase. In this paper, PCT applications which designate the EPO are referred to as EPO designated PCT applications, and PCT applications which enter the EPO regional phase are referred to as EPO regional phase PCT applications. The PCT procedure starts with the international phase and concludes with the national/regional phase.

1. The European Patent Convention was signed in 1973 and entered into force in 1977. Currently 28 countries are party to the treaty. In addition, the EPO has "extension agreements" with five countries, which allows the possibility of extending European patents to those countries upon request at the time of European patent application. The EPO is not an institution of the European Union. 
Prior to the entry into force of the EPC and the PCT procedures, applicants had to file separate patent applications to seek patent rights in EPC countries. For example, four separate applications were necessary to obtain patent rights in France, Germany, the Netherlands and the United Kingdom. Under the EPC and the PCT procedures, applicants have the possibility to seek patent rights in all the EPC member countries by filing a single European patent application or a single PCT application that designates the EPO. Applicants have the choice of the following routes to seek patent rights in the EPC countries: file a separate application to the relevant national patent office (national procedure); file a single EPO application that designates the relevant EPC countries (EPO procedure); or file a single PCT application that designates the EPO (PCT procedure).

There are various factors (e.g. cost of patenting, time taken to grant patents, differences in national patent office rules regarding the scope of patents, etc.) that will influence the decision on whether to follow the national, the EPO, or the PCT procedure. The total cost of obtaining patents in different EPC countries will be a major factor. It is difficult to estimate the average cost for obtaining a European patent, ${ }^{2}$ but a commonly held view is that it is worthwhile to file for EPO patents if the applicants intend to obtain patent rights in more than three countries (Akers, 1999, Grupp and Schmoch, 1999). However, it should be noted that EPO patent fees have been reduced in recent years. The first reduction was introduced in July $1997,{ }^{3}$ which was followed by a second reduction, introduced in July $1999{ }^{4}$

Patent applications at the EPO originate from either direct EPO applications (i.e. patent applications filed at the EPO without the use of the PCT procedure) or from PCT applications (i.e. patent applications filed at the EPO on the basis of the PCT procedure). Both procedures should thus be taken into consideration when reporting EPO patent statistics. But the decision on whether to include international phase PCT application data (i.e. PCT applications which designate the EPO) or only the national/regional phase PCT application data (i.e. PCT applications which enter the EPO regional phase) will have a significant impact on EPO patent statistics.

Data on EPO designated PCT applications, EPO regional phase PCT applications, and direct EPO applications are presented with a view to examine the impact of PCT data on EPO patent statistics and to address the following questions:

- Whether or not to include PCT data in the reporting of EPO patent statistics?

- Whether to include all EPO designated PCT data or only the EPO regional phase PCT data?

- What impact does the inclusion (or exclusion) of PCT data have on the EPO patent statistics?

At the time of PCT filing, the applicant has to designate the countries in which patent rights for the invention are desired..$^{5}$ It is possible to designate the EPO in order to seek patent rights in the EPC countries. The available statistics show that the EPO is designated in the majority of PCT applications, but not in all. As we are concerned with the impact of PCT data on EPO patent statistics, only the EPO designated PCT data will be considered, because PCT applications which do not designate the EPO will have no impact on the EPO statistics.

2. The cost of patent filing depends on the size of the patent document, number of claims, patent attorney fees, translation costs, etc.

3. http://www.european-patent-office.org/legal/anc_reg/e/pdf/1997z215.pdf.

4. http://www.european-patent-office.org/news/pressrel/7_98_e.htm.

5. A new designation system entered into force in January 2004 (see Annex A), where the applicant will obtain automatic all-inclusive coverage of all designations available under the PCT procedure. However the new designation system is not a concern here as the analysis is based on PCT filings up to 2000. 


\section{DSTI/DOC(2005)2}

\section{PCT and EPO patent applications}

In 2000, the total number of EPO designated PCT applications was estimated at around 102836 (Table A1). Between 1986 and 2000, ${ }^{6}$ the growth rate of the EPO designated PCT applications for France, Germany, Japan and the United States was similar to the overall growth rate (20\% a year), whereas the growth rate for the United Kingdom (15.5\%) was below the overall growth rate. A small number of countries accounted for the majority of the EPO designated PCT applications. The United States is by far the largest user of the PCT procedure (41\% of the total EPO designated PCT applications), followed by Germany (13\%), Japan (10\%), the United Kingdom (5\%) and France (4\%). Between 1986 and 2000, there has been a notable increase in the country shares for Canada, Korea, the Netherlands and the United States, while it decreased for Australia, Sweden and the United Kingdom.

Direct EPO patent applications (i.e. patent applications filed at the EPO without the use of the PCT procedure) amounted to 48407 in 2000, representing a 23\% increase from the 1986 level (Table A2). However, the total number of direct EPO patent applications is well below that of EPO designated PCT applications (102 836). The annual average growth rate of direct EPO applications is relatively modest in comparison to the growth rate of EPO designated PCT applications.

Figure 1 presents the trend of direct EPO applications, EPO designated PCT applications, and EPO regional phase PCT applications. The number of direct EPO applications increased during the late 1980s, followed by a steady decline until the mid-1990s, while there has been a slight increase since 1995. In contrast, the number of EPO designated PCT applications and EPO regional phase PCT applications has increased over the same period. Applicants are increasingly using the PCT procedure for EPO patent applications. In 1998, EPO regional phase PCT applications accounted for 52\% of all EPO applications, a substantial increase from the 1986 share (Table A3). The increase in the use of the PCT procedure for EPO patent applications is observed for the majority of OECD countries, as the share of EPO regional phase PCT applications in total EPO applications in the late 1990s is higher than that for the late 1980s.

Applicants are increasingly using the PCT procedure to file patent applications at the EPO, as is reflected in the substantial increase in the number of EPO designated PCT applications and in the number of EPO regional phase PCT applications. If PCT applications data are not taken into consideration, EPO statistics will provide only a partial picture of the level of patent activity at the EPO. Therefore, PCT data should be included in the reporting of EPO patent statistics. The question of whether to include the EPO designated PCT data or the EPO regional phase PCT data is addressed below.

6. Comparison of the PCT applications data published by the World Intellectual Property Organisation (WIPO) and those available at the OECD shows that the data series are similar, but not identical due to different counting procedure. The OECD collects and processes raw patent data from the EPO and USPTO, and work is ongoing to incorporate the JPO data in the OECD database. The EPO supplies the OECD with the EUREG and the DocDB database, JPO supplies the OECD with JPO data and the USPTO data are downloaded from the USPTO Internet site. In this paper, PCT and EPO data are derived from the OECD patent database, because of the possibility to compile patent indicators according to the priority date and the possibility to identify the EPO designated PCT applications which enter the EPO regional phase. PCT and EPO patent data are available from 1978 onwards but the number of PCT and EPO applications during the transition period (early 1980s) was relatively low and fluctuated heavily from year to year. Hence, data from 1986 onwards are used in the analysis. 


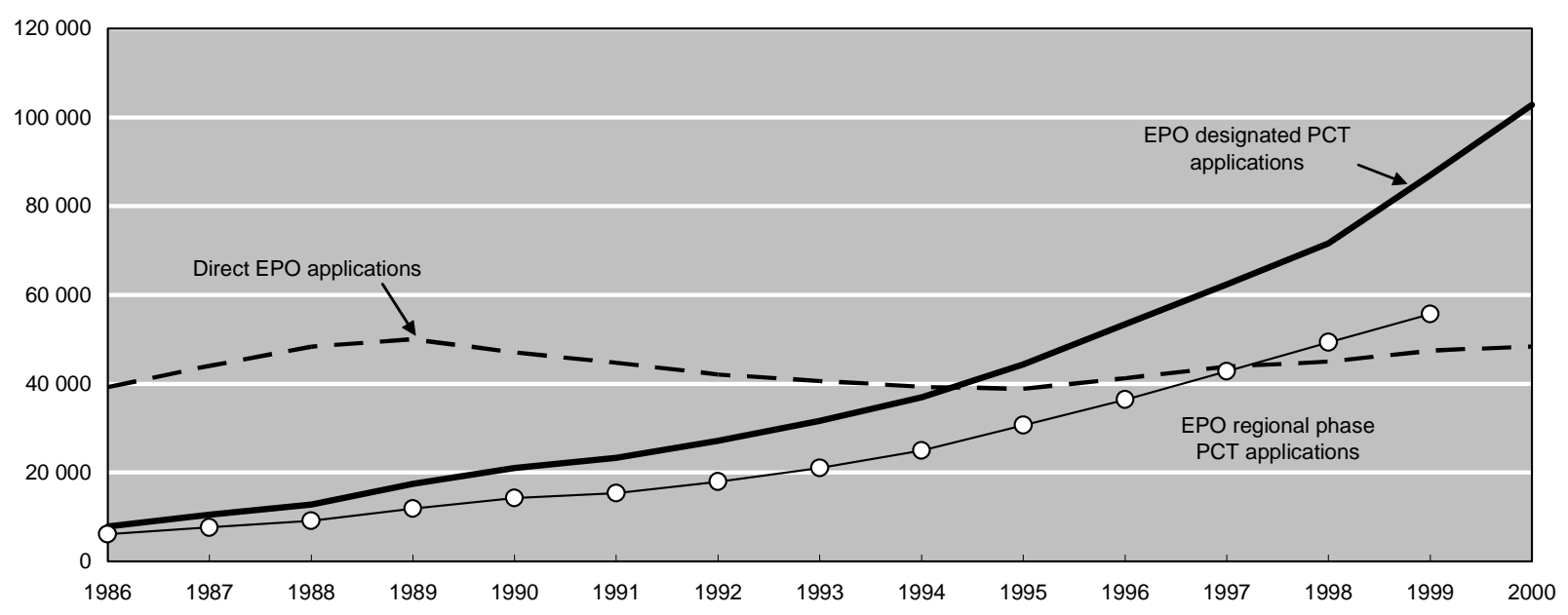

Source: OECD, Patent Database, November 2003.

The issue of whether to include EPO designated PCT data or EPO regional phase PCT data in reporting EPO patent statistics will be decided by addressing the following questions:

- What proportion of EPO designated PCT applications proceeds to the EPO regional phase?

- What are the impacts of the EPO designated PCT data and the EPO regional phase PCT data on EPO patent statistics?

As explained above, the PCT procedure consists of two main phases: $a$ ) an international phase; and b) a PCT national/regional phase. The PCT procedure starts with the international phase (i.e. by filing a PCT application, in this case, by the filing of an EPO designated PCT application) and concludes with the national/regional phase (i.e. in this case, the EPO designated PCT application proceeds to the EPO regional phase). The data shows that not all EPO designated PCT applications proceed to the EPO regional phase. For various reasons, the applicant may decide not to pursue EPO designated PCT applications to the EPO regional phase.

In $1998,{ }^{7}$ the total number of EPO regional phase PCT applications filed at the EPO amounted to around 49355, representing an annual average growth rate of $19 \%$ since 1986 (Table A4). In terms of country shares, the United States $(38.4 \%)$ accounted for the largest share, followed by Germany (16.4\%) and Japan (9.5\%). However, the EPO regional phase PCT applications share of the United States is lower than its share in EPO designated PCT applications. Germany, on the other hand, has a higher share of EPO regional PCT applications relative to its share in EPO designated PCT applications, which implies that German applicants are more likely to proceed to the EPO regional phase than American applicants. Approximately $69 \%$ of EPO designated PCT applications proceed to the EPO regional phase (Figure 2) and this ratio remained more or less stable during the 1990s. The OECD-wide average masks substantial differences in the percentage of EPO designated PCT applications that proceed to the EPO regional phase

7. Because of the legal time lag between the priority date and entry in the EPO regional phase (which can take between 19 and 31 months), 1999 is the latest year for which EPO regional phase PCT applications data (based on priority date) are available. However, analysis of the data shows that 1999 data are partial, hence data is reported up to 1998 . 


\section{DSTI/DOC(2005)2}

(Table A5). In 1998, the ratio of EPO regional phase PCT applications to EPO designated PCT applications ranged between 35\% (Poland) and 83\% (Luxembourg and the Netherlands). Belgium, France, Germany, Luxembourg and the Netherlands have a high ratio of EPO regional phase PCT applications to EPO designated PCT applications (Figure 2). The United States accounted for the largest share of EPO designated PCT applications. However, relative to France, Germany and the United Kingdom, the US share of EPO designated PCT applications that proceed to the EPO regional phase is low.

Figure 2. EPO regional phase PCT applications as a percentage of EPO designated PCT applications (priority date), $1991 \& 1998$

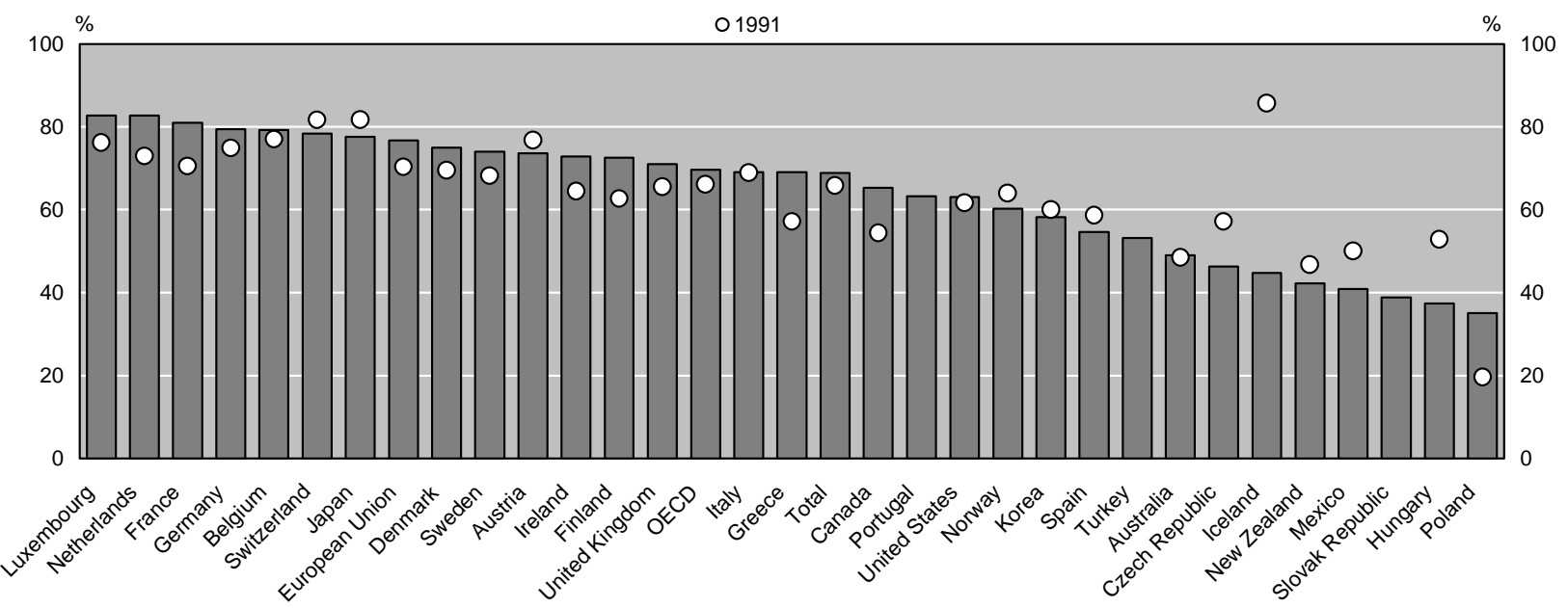

Source: OECD, Patent Database, November 2003.

\section{Impact of PCT applications on EPO data}

To measure the impact of EPO designated PCT applications and EPO regional phase PCT applications on EPO patent statistics, we estimate two different EPO data series using the following definitions:

- "Potential EPO applications"8 is the sum of the number of direct EPO applications and EPO designated PCT applications.

- "Effective EPO applications"9 is the sum of direct EPO applications and EPO regional phase PCT applications.

The number of potential EPO applications and the number of effective EPO applications, as defined above, are reported in Table A6 and Table A7, respectively. The share of potential EPO applications which is converted into effective EPO applications has been decreasing over time. In 1998, 81\% of potential EPO applications were converted into effective EPO applications, whereas during the late 1980s the share was

8. The EPO designated PCT applications have the potential to become EPO applications by proceeding to the EPO regional phase. However, since not all EPO designated applications proceed to the EPO regional phase, we use the term "potential EPO applications".

9. The EPO designated PCT applications proceed to the EPO regional phase and become effective EPO applications, therefore we use the term "effective EPO applications". 
above $90 \%$ (Table A8). There is substantial cross-country variation in the realisation of potential EPO applications into effective EPO applications (Figure 3).

If all EPO designated PCT applications data are included in the calculation of EPO patent statistics (potential EPO applications), then the number of EPO patent applications will be overestimated ${ }^{10}$ by $23.7 \%$ (i.e. the difference between potential and effective EPO applications). There is a significant difference in the level of overestimation across OECD countries; ranging from 9\% for Japan to 148\% for Hungary (Table 1). The number of patent applications for the United States is overestimated by 39\%, which is significantly above that of the European Union (15\%) and Japan (9\%). This is due to the fact that the United States is by far the largest user of the PCT procedure (accounting for $41.9 \%$ of EPO designated PCT applications). However, it has a low ratio of EPO regional phase PCT applications to EPO designated PCT applications, which implies that a significant number of EPO designated PCT applications originating from the United States do not proceed to the EPO regional phase.

Figure 3. Effective EPO applications as a percentage of potential EPO applications, 1991 \& 1998

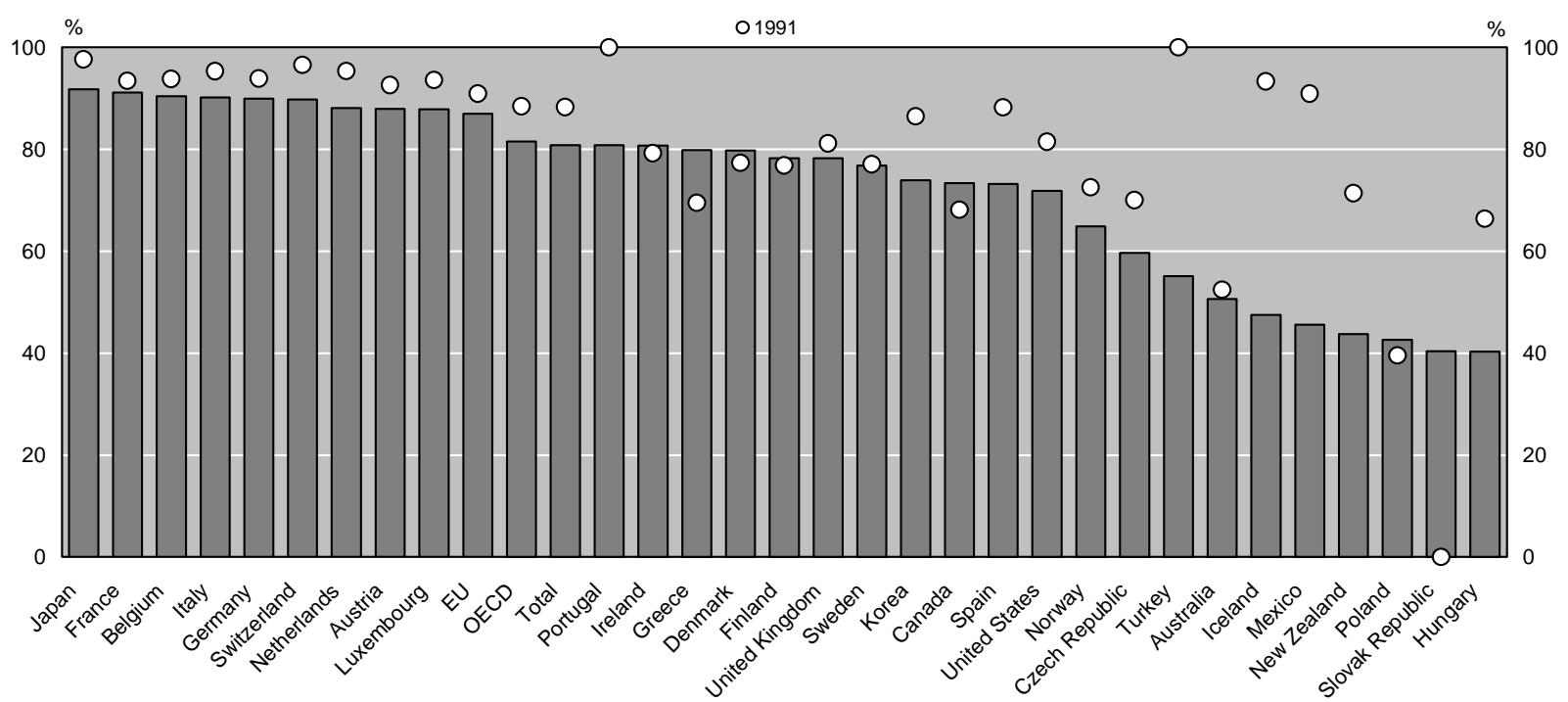

Source: OECD, Patent Database, November 2003.

The impact of including all EPO designated PCT applications is to overestimate the number of EPO patent applications for non-EPC countries: 13 of the top 15 countries with the largest percentage of overestimation are non-EPC contracting states ${ }^{11}$ - the exceptions being Spain and Sweden. In contrast, only a low level of overestimation is reported for the EPC countries. For example, the number of patent filings for Belgium, France and Italy would only be overestimated by around 10\%. If all EPO designated PCT applications data are included in the calculation of EPO patent statistics, it will thus overestimate the total number of EPO patent applications and it will also introduce a bias in favour of the non-EPC countries.

10. Here we use the term "overestimated" because the number of EPO applications based on this definition is below the effective number of EPO applications.

11. These countries were not contracting states to the EPC in 1998. However, some have since become party to the EPC convention, e.g. the Czech Republic and Hungary (2002). 


\section{DSTI/DOC(2005)2}

The country share of the United States based on potential EPO applications is 3.8 percentage points higher than the share based on the effective EPO applications (Figure 4). For the European Union, Germany and Japan, the country shares based on potential EPO applications are lower than the country shares based on the effective EPO applications. Notable differences in the ranking (based on the share in potential and effective EPO applications) are observed for Belgium, Greece, Portugal and Turkey (their ranking based on effective EPO applications is higher); and for Australia, Hungary and Poland (their ranking based on effective EPO applications is lower) (Table 1).

Table 1. Impact of EPO designated PCT applications and EPO regional phase PCT applications data on EPO patent statistics, 1998

\begin{tabular}{|c|c|c|c|c|c|c|c|c|c|c|}
\hline & \multicolumn{3}{|c|}{$\begin{array}{c}\text { Country rank } \\
\text { based on share }\end{array}$} & \multicolumn{3}{|c|}{ Country share } & \multicolumn{3}{|c|}{$\begin{array}{c}\text { Average annual } \\
\text { growth rate 1986-98 }\end{array}$} & \multirow[b]{2}{*}{$\begin{array}{c}\text { Overestimation } \\
(\%)\end{array}$} \\
\hline & Effective & Potential & Direct & Effective & Potential & Direct & Effective & Potential & Direct & \\
\hline $\begin{array}{l}\text { Total } \\
\text { OECD }\end{array}$ & - & $\begin{array}{l}- \\
-\end{array}$ & - & $\begin{array}{r}100.0 \\
97.9\end{array}$ & $\begin{array}{r}100.0 \\
97.1\end{array}$ & $\begin{array}{r}100.0 \\
98.4\end{array}$ & $\begin{array}{l}6.3 \\
6.2\end{array}$ & $\begin{array}{l}7.9 \\
7.7\end{array}$ & $\begin{array}{l}1.1 \\
1.1\end{array}$ & $\begin{array}{l}23.7 \\
22.7\end{array}$ \\
\hline $\begin{array}{l}\text { European Union } \\
\text { United States } \\
\text { Germany } \\
\text { Japan } \\
\text { France }\end{array}$ & $\begin{array}{l}1 \\
2 \\
3 \\
4 \\
5\end{array}$ & $\begin{array}{l}1 \\
2 \\
3 \\
4 \\
5\end{array}$ & $\begin{array}{l}1 \\
4 \\
2 \\
3 \\
5\end{array}$ & $\begin{array}{r}44.8 \\
30.1 \\
20.0 \\
16.2 \\
7.0\end{array}$ & $\begin{array}{r}41.6 \\
33.8 \\
18.0 \\
14.3 \\
6.2\end{array}$ & $\begin{array}{r}47.7 \\
20.9 \\
23.9 \\
23.6 \\
8.5\end{array}$ & $\begin{array}{l}5.5 \\
7.2 \\
5.8 \\
6.3 \\
4.9\end{array}$ & $\begin{array}{l}6.5 \\
9.7 \\
6.6 \\
6.9 \\
5.6\end{array}$ & $\begin{array}{r}0.7 \\
-0.5 \\
1.7 \\
3.9 \\
1.0\end{array}$ & $\begin{array}{r}14.9 \\
39.2 \\
11.2 \\
8.9 \\
9.8\end{array}$ \\
\hline $\begin{array}{l}\text { United Kingdom } \\
\text { Switzerland } \\
\text { Netherlands } \\
\text { Italy } \\
\text { Sweden }\end{array}$ & $\begin{array}{r}6 \\
7 \\
8 \\
9 \\
10\end{array}$ & $\begin{array}{r}6 \\
7 \\
8 \\
9 \\
10\end{array}$ & $\begin{array}{r}8 \\
7 \\
9 \\
6 \\
15\end{array}$ & $\begin{array}{l}4.4 \\
3.2 \\
3.1 \\
3.1 \\
2.4\end{array}$ & $\begin{array}{l}4.5 \\
2.9 \\
2.8 \\
2.8 \\
2.5\end{array}$ & $\begin{array}{l}2.9 \\
3.9 \\
2.3 \\
4.9 \\
0.7\end{array}$ & $\begin{array}{l}2.0 \\
4.6 \\
5.1 \\
5.2 \\
8.2\end{array}$ & $\begin{array}{l}3.7 \\
5.4 \\
6.1 \\
6.0 \\
9.1\end{array}$ & $\begin{array}{r}-5.9 \\
1.0 \\
-3.4 \\
3.4 \\
-3.6\end{array}$ & $\begin{array}{l}27.9 \\
11.4 \\
13.5 \\
10.9 \\
30.2\end{array}$ \\
\hline $\begin{array}{l}\text { Canada } \\
\text { Finland } \\
\text { Belgium } \\
\text { Korea } \\
\text { Austria } \\
\text { Denmark }\end{array}$ & $\begin{array}{l}11 \\
12 \\
13 \\
14 \\
15 \\
16\end{array}$ & $\begin{array}{l}11 \\
12 \\
15 \\
13 \\
16 \\
17\end{array}$ & $\begin{array}{l}13 \\
14 \\
10 \\
12 \\
11 \\
17\end{array}$ & $\begin{array}{l}1.4 \\
1.3 \\
1.0 \\
0.9 \\
0.9 \\
0.7\end{array}$ & $\begin{array}{l}1.6 \\
1.4 \\
0.9 \\
1.0 \\
0.8 \\
0.7\end{array}$ & $\begin{array}{l}0.9 \\
0.7 \\
1.2 \\
1.0 \\
1.1 \\
0.4\end{array}$ & $\begin{array}{r}9.9 \\
15.7 \\
7.7 \\
42.3 \\
4.7 \\
10.3\end{array}$ & $\begin{array}{r}12.6 \\
16.6 \\
8.5 \\
41.3 \\
5.7 \\
10.7\end{array}$ & $\begin{array}{r}0.2 \\
9.8 \\
3.5 \\
57.2 \\
2.0 \\
2.7\end{array}$ & $\begin{array}{l}36.2 \\
27.7 \\
10.5 \\
35.3 \\
13.7 \\
25.3\end{array}$ \\
\hline $\begin{array}{l}\text { Australia } \\
\text { Spain } \\
\text { Norway } \\
\text { Ireland } \\
\text { Luxembourg }\end{array}$ & $\begin{array}{l}17 \\
18 \\
19 \\
20 \\
21\end{array}$ & $\begin{array}{l}14 \\
18 \\
19 \\
20 \\
22\end{array}$ & $\begin{array}{l}21 \\
16 \\
19 \\
18 \\
20\end{array}$ & $\begin{array}{l}0.6 \\
0.5 \\
0.3 \\
0.2 \\
0.2\end{array}$ & $\begin{array}{l}1.0 \\
0.6 \\
0.4 \\
0.2 \\
0.1\end{array}$ & $\begin{array}{l}0.1 \\
0.6 \\
0.1 \\
0.2 \\
0.1\end{array}$ & $\begin{array}{r}3.5 \\
11.9 \\
9.5 \\
13.8 \\
3.3\end{array}$ & $\begin{array}{r}6.5 \\
14.8 \\
12.0 \\
15.9 \\
4.4\end{array}$ & $\begin{array}{r}-10.1 \\
6.6 \\
-0.7 \\
4.5 \\
-5.3\end{array}$ & $\begin{array}{l}97.5 \\
36.6 \\
54.1 \\
23.9 \\
13.9\end{array}$ \\
\hline $\begin{array}{l}\text { New Zealand } \\
\text { Greece } \\
\text { Czech Republic } \\
\text { Hungary } \\
\text { Turkey }\end{array}$ & $\begin{array}{l}22 \\
23 \\
24 \\
25 \\
26\end{array}$ & $\begin{array}{l}21 \\
25 \\
24 \\
23 \\
28\end{array}$ & $\begin{array}{l}25 \\
22 \\
23 \\
27 \\
29\end{array}$ & $\begin{array}{l}0.1 \\
0.1 \\
0.1 \\
0.0 \\
0.0\end{array}$ & $\begin{array}{l}0.2 \\
0.1 \\
0.1 \\
0.1 \\
0.0\end{array}$ & $\begin{array}{l}0.0 \\
0.1 \\
0.0 \\
0.0 \\
0.0\end{array}$ & $\begin{array}{r}8.9 \\
15.4 \\
10.5 \\
-7.0 \\
23.8\end{array}$ & $\begin{array}{l}16.7 \\
17.6 \\
15.4 \\
-0.5 \\
30.1\end{array}$ & $\begin{array}{r}-13.5 \\
7.8 \\
2.8 \\
-17.8 \\
0.0\end{array}$ & $\begin{array}{r}128.5 \\
25.2 \\
67.6 \\
148.1 \\
81.3\end{array}$ \\
\hline $\begin{array}{l}\text { Portugal } \\
\text { Mexico } \\
\text { Poland } \\
\text { Iceland } \\
\text { Slovak Republic }\end{array}$ & $\begin{array}{l}27 \\
28 \\
29 \\
30 \\
31\end{array}$ & $\begin{array}{l}29 \\
27 \\
26 \\
30 \\
31\end{array}$ & $\begin{array}{l}24 \\
28 \\
26 \\
30 \\
31\end{array}$ & $\begin{array}{l}0.0 \\
0.0 \\
0.0 \\
0.0 \\
0.0\end{array}$ & $\begin{array}{l}0.0 \\
0.0 \\
0.0 \\
0.0 \\
0.0\end{array}$ & $\begin{array}{l}0.0 \\
0.0 \\
0.0 \\
0.0 \\
0.0\end{array}$ & $\begin{array}{r}14.5 \\
14.9 \\
-1.7 \\
13.9 \\
. .\end{array}$ & $\begin{array}{r}16.5 \\
22.7 \\
5.5 \\
18.9 \\
. .\end{array}$ & $\begin{array}{r}9.6 \\
-0.7 \\
-11.8 \\
-5.6 \\
. .\end{array}$ & $\begin{array}{r}23.7 \\
119.6 \\
134.5 \\
110.5 \\
147.9\end{array}$ \\
\hline
\end{tabular}

Direct EPO applications refer to applications filed at the EPO without the use of the PCT procedure.

Potential EPO applications are defined as the sum of the number of direct EPO applications and EPO designated PCT applications. Effective EPO applications are defined as the sum of direct EPO applications and EPO regional phase PCT applications.

Overestimation is defined as the difference between the total number of potential and effective EPO patent applications.

Source: OECD, Patent Database, November 2003. 
Figure 4. Difference between the share of potential and effective EPO applications, 1998 country share in potential EPO applications - country share in effective EPO applications

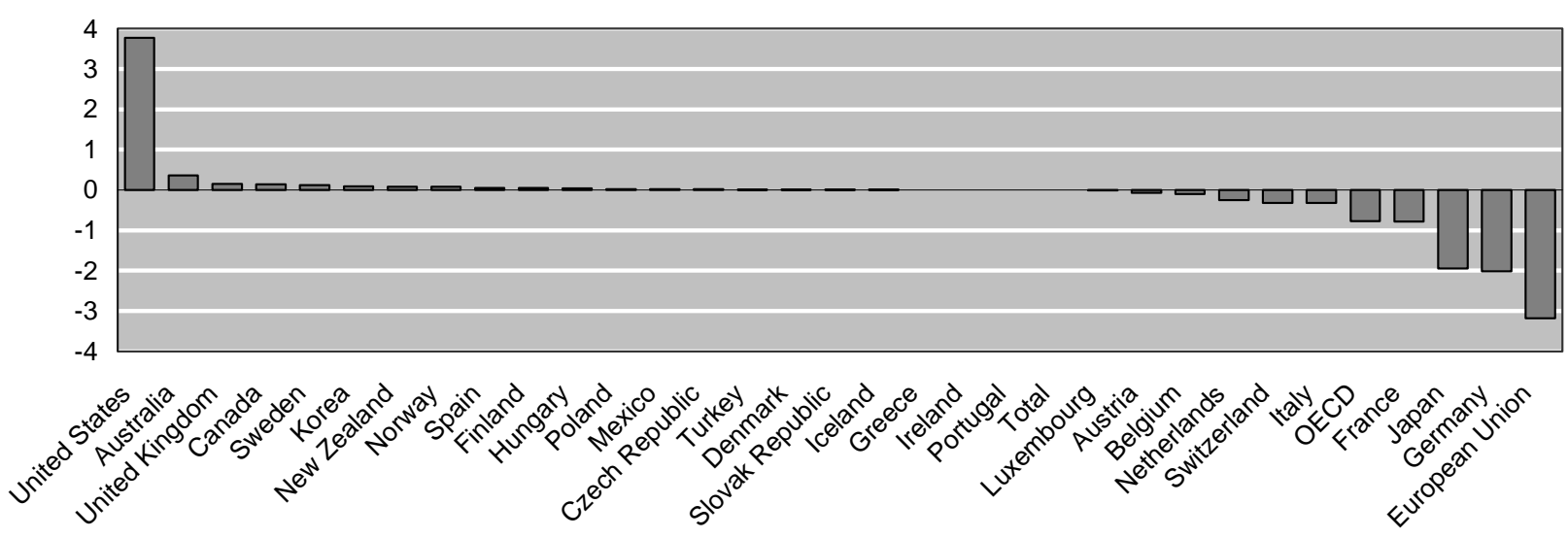

Source: OECD, Patent Database, November 2003.

The decision on whether to include all EPO designated PCT applications or only the EPO regional phase PCT applications thus has a significant impact on EPO patent statistics. It could be argued that all EPO designated PCT applications, whether or not they subsequently proceed to the EPO regional phase, should be included because they represent - at the time of the application - the intention of the applicants to seek patents rights. Furthermore, within the context of work on science and technology, patent indicators are used to measure innovative activities. Since EPO designated PCT applications represent the innovative activities of applicants, they should be taken into account.

On the other hand, the following arguments can be used against the inclusion of EPO designated PCT applications in the calculation of EPO patent statistics:

- Applications do not proceed to the regional phase: a significant number (31\%) of EPO designated PCT applications do not proceed to the EPO regional phase.

- Reduction in the comparability of EPO patent statistics: combining patent applications that proceed to the EPO (i.e. direct EPO applications) and the EPO designated PCT applications which do not proceed to the EPO will have a negative impact on the comparability of statistics.

- Overestimation: inclusion of EPO designated PCT applications will overestimate the total number of EPO patent applications (i.e. inflate the figures) and it will introduce a bias in favour of the non-EPC countries (Table 1 and Figure 4).

- Lower grant rate: in terms of grant rates, EPO designated PCT applications are not comparable to direct EPO applications. Between 1986 to 1994, the grant rate of the EPO designated PCT applications was some 20 percentage points below that of the direct EPO applications and EPO regional PCT applications (Figure 5). ${ }^{12}$ The reason for the low grant rate for EPO designated PCT applications is that a large number of EPO designated PCT applications do not proceed to the EPO regional phase.

12. The apparent decrease in grant rates for later years (1995 to 1999) is due to the time lag between the priority date and the grant date. A substantial number of patent applications filed at the EPO are in the examination phase but have not yet being fully processed (i.e. decision has not been taken on whether to grant (or reject) a patent). For this reason, the grant rates from 1995 onwards show a downward trend. 


\section{DSTI/DOC(2005)2}

- $\quad$ Another argument put forward by some authors (e.g. Schmoch et al., 1998) is that in cases where the applicant is uncertain about the potential market value of the invention, the PCT procedure may be used to "buy" additional time to assess the potential of the invention. Hence EPO designated PCT applications are not comparable to direct EPO applications. Furthermore, if the applicant is uncertain about the patentability of the invention, the PCT procedure may be used by the applicant to obtain additional information about the prior art (through the International Search Report) and patentability of the claims (through the International Preliminary Examination Report). If these reports are unfavourable the applicant might decide not to proceed to the EPO regional phase.

For the reasons outlined above (applications do not proceed to the regional phase, overestimation, lower grant rate), it is recommended that EPO designated PCT data should not be included in EPO patent statistics. Only the EPO regional phase PCT data should be included in the EPO patent statistics because: they are effective EPO applications; they constitute a significant proportion of total EPO applications; and in terms of grant rates, they are comparable to direct EPO applications.

However, a major drawback to including EPO regional phase PCT applications data in the EPO patent data is timeliness. The time lag between priority date and the EPO regional phase entry can be between 19 and 31 months. Taking other administrative delays into consideration, it could take around 36 months before the information becomes publicly available. One way to deal with the timeliness problem is to estimate the EPO regional phase PCT applications data.

Figure 5. Grant rates: direct EPO applications, EPO designated PCT applications and EPO regional phase PCT applications

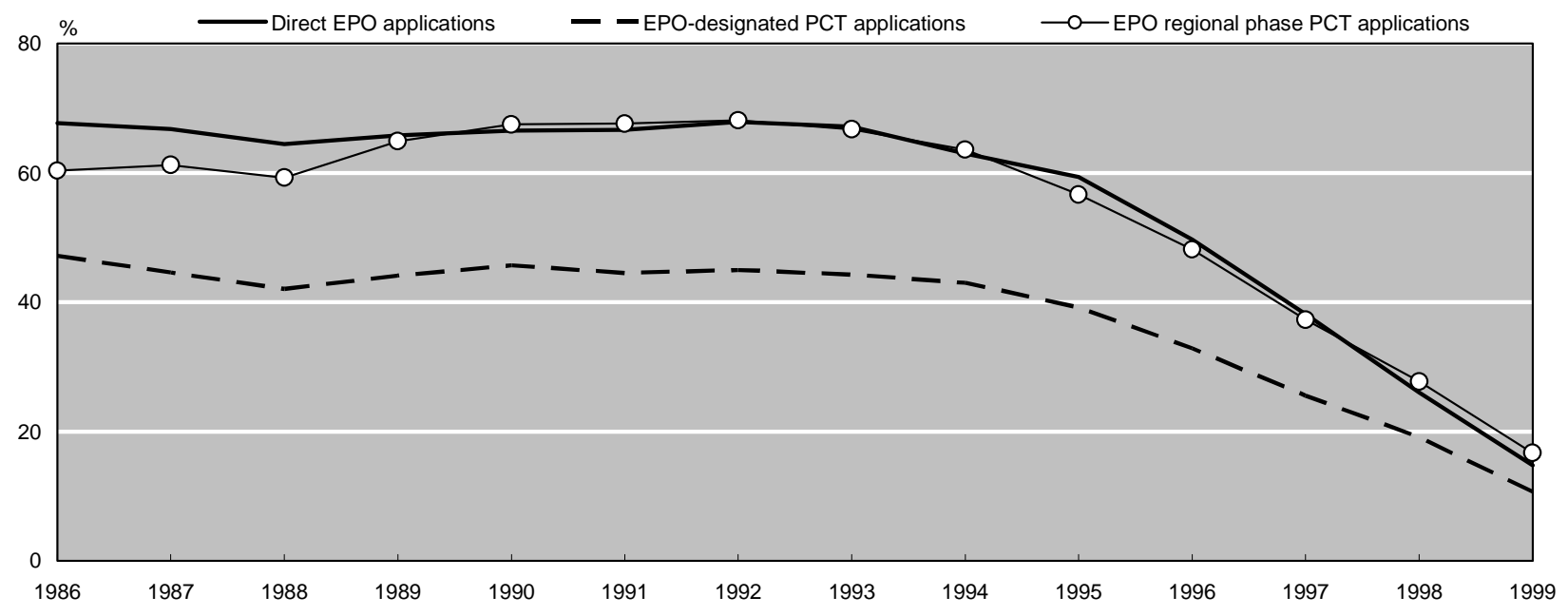

The apparent decrease in grant rates for later years (1995 to 1999) is due to the time lag between the priority date and the grant date. A substantial number of patent applications filed at the EPO are in the examination phase but have not yet been fully processed (i.e. decision has not been taken on whether to grant (or reject) a patent). For this reason, the grant rates from 1995 onwards show a downward trend.

Source: OECD, Patent Database, November 2003.

\section{Methods for nowcasting EPO data}

As mentioned above, the timeliness of patent indicators is a major problem when EPO regional phase PCT data is included in EPO patent statistics. For example in 2003, EPO designated PCT applications and 
direct EPO applications data are available up to 2000 (based on priority date). ${ }^{13}$ The EPO regional phase PCT data are only available up to 1998 (1999 data are partial). As a consequence, the total number of EPO patent applications (number of direct EPO applications plus number of EPO regional phase PCT applications) can only be reported up to 1998. Total number of EPO patent applications can be reported up to 2000, by nowcasting (forecasting the recent past) the EPO regional phase PCT data for 1999 and 2000. Reporting EPO patent statistics beyond 2000 would require nowcasting data for both the EPO regional phase PCT applications data and direct EPO applications data. ${ }^{14}$

In this paper, five different methods are explored to test the possibility of nowcasting total EPO patent applications data. In order to identify a suitable method for nowcasting EPO patent data, the available data is split into two samples: "an estimation sample" (1986 to 96) and "a validation sample" (1997 to 1999). The estimation sample is used to nowcast the 1997 to 1999 EPO patent data, whereas the validation sample is used to compare the estimated data with actual data.

\section{Method A}

The number of EPO regional phase PCT applications for the current year is estimated using the ratio of EPO regional phase PCT applications to EPO designated PCT applications of the previous year. Here the assumption is that the ratio (EPO regional phase PCT applications over EPO designated PCT applications) is stable over time. The estimated number of EPO regional phase PCT applications data is added to the number of direct EPO applications data to obtain the total number of EPO applications. If the EPO regional phase PCT applications over EPO designated PCT applications ratio is stable over time, this method will produce an accurate estimate, as it incorporates the latest trend in EPO designated PCT applications. The formula used to estimate the total number of EPO patent applications is:

$$
\begin{aligned}
& T E P O_{t}=E P C T_{t}+D E P O_{t} \\
& E P C T_{t}=\left(\frac{E P C T_{t-1}}{P C T_{t-1}}\right) \times P C T_{t}
\end{aligned}
$$

where $T E P O=$ total number of EPO applications; $E P C T=$ EPO regional phase PCT applications; $D E P O=$ direct EPO applications; and $P C T=$ EPO designated PCT applications. The time period is denoted by $t$.

The rationale behind this method is to use the maximum amount of available information. The total number of EPO patent applications is the sum of direct EPO applications and EPO regional phase PCT applications. Data on direct EPO applications is available but data on EPO regional phase PCT applications is missing. However, information on EPO designated PCT applications is available which is used to estimate the EPO regional phase PCT data series. This will capture the recent trends in PCT patent applications.

13. OECD patent indicators are calculated according to priority date, which is the first date of filing of a patent application, anywhere in the world, to protect an invention. The priority date is the earliest and therefore closest to the invention date. For further details about methodological choices associated with calculating patent indicators, see Compendium of Patent Statistics (OECD, 2004).

14. EPO regional phase PCT applications data and direct EPO applications data should be available up to 2001 (2002) for priority date (for application date). However, analysis of the DocDB database (maintained by EPO) shows that complete data series for EPO regional phase PCT applications data and direct EPO applications data are available up to 2000 and partial data is available for 2001 and 2002. 


\section{Method B}

Instead of depending on the ratio of EPO regional phase PCT applications to EPO designated PCT applications for one year (as is the case for method A), this method takes consideration of the average ratio of the previous two years to estimate EPO regional phase PCT applications data, which is then combined with direct EPO applications data to obtain the total number of EPO patent applications. The average ratio of the previous two years is taken into consideration to neutralise any sharp changes in the ratio of any one year (this tends to happen for countries with a small number of patent applications). Analysis of the available data show that the ratio of EPO regional phase PCT applications to EPO designated PCT applications of large patenting countries tends to be stable, whereas for small patenting countries (e.g. Iceland, Mexico, Poland, etc.) it tends to fluctuate from year-to-year. The formula used to estimate the total number of EPO patent applications data is:

$$
\begin{aligned}
T E P O_{t} & =E P C T_{t}+D E P O_{t} \\
E P C T_{t} & =\left(\frac{E P C T_{t-1}+E P C T_{t-2}}{P C T_{t-1}+P C T_{t-2}}\right) \times P C T_{t}
\end{aligned}
$$

where $T E P O=$ total EPO patent applications; $E P C T=$ EPO regional phase PCT applications; $D E P O=$ direct EPO applications; and $P C T=$ EPO designated PCT applications. The time period is denoted by $t$.

The rationale behind this method is the same as the rationale behind method $\mathrm{A}$ - to use the maximum amount of information that is available at the time of estimation. The only difference is that the ratio of EPO regional phase PCT applications to EPO designated PCT applications of the previous two years is used instead of a one year ratio, in order to smooth out fluctuations in the ratio for smaller countries.

\section{Method C}

Rather than assuming the ratio of EPO regional phase PCT applications to EPO designated PCT applications to be constant over time (as for methods A and B), a linear regression using the method of least squares is used to estimate the ratio. This ratio is then applied to the EPO designated PCT applications data to estimate the number of EPO regional phase PCT applications. The estimated number of EPO regional phase PCT applications is then added to the direct EPO applications to obtain total EPO applications. The rationale behind this method is to treat the transfer rate as dynamic rather than static (as in method A and B). The following linear regression is used to estimate the ratio of EPO regional phase PCT applications to EPO designated PCT application:

$$
\operatorname{REPCT}_{t}=a+b t
$$

where REPCT = ratio of EPO regional phase PCT applications to EPO designated PCT applications; $a$ and $b=$ unknown parameters. The time period is denoted by $t$.

\section{Method D}

Autoregressive Integrated Moving Averages (ARIMA) models can also be used to nowcast the EPO regional phase PCT data. The first step in this procedure is to make the EPO regional phase PCT data series stationary (i.e. data series with mean, variance and covariance constant over time). To make the series stationary, a logarithmic transformation is applied to stabilise the variance and the first difference is taken to make the mean stationary (for further details, see Dehon and Van Pottelsberghe, 2003). Country 
specific ARIMA models are employed to nowcast the EPO regional phase PCT applications data, which are then added to the direct EPO applications data to obtain the total number of EPO applications. The main weakness of this method is that it does not take into consideration the latest development in EPO designated PCT applications. For example, if information on EPO regional phase PCT applications data and EPO designated PCT applications data is available up to 1996 and 1998, respectively, this method will only use information up to 1996 (EPO regional phase PCT applications information) and disregard the latest available information (up to 1998). The following first order AR (autoregressive) and MA (moving average) models are used to estimate the EPO regional phase PCT applications data series:

$$
A R\left((1) \quad X_{t}=\delta+\Phi X_{t-1}+A_{t}\right.
$$

where $X_{t}$ is the log first difference of EPO regional phase PCT applications data; $A_{t}$ is white noise with mean zero and variance $\sigma^{2}$; and $\delta$ and $\Phi$ are the unknown parameters. An autoregressive model is simply a linear regression of the current value of the series against one or more prior values of the series.

$$
M A\left((1) \quad X_{t}=\mu+A_{t}-\theta A_{t-1}\right.
$$

where $X_{t}$ is the log first difference of EPO regional phase PCT applications; $\mu$ is the mean of the series; $A_{t}$ is white noise with mean zero and variance $\sigma^{2}$; and $\theta$ is the unknown parameter. A moving average model is a linear regression of the current value of the series against the white noise of one or more prior values of the series.

Second order AR and MA were tested for nowcasting the EPO regional phase PCT applications data, but these did not improve the results from the first order AR and MA models. As mentioned above, a country specific model was fitted and the decision on whether to use an AR or MA model for a country is dictated by the performance of the model (e.g. if the MA model produced a better result relative to the AR model, then an MA model was used for that country to estimate EPO regional phase PCT applications).

The rationale behind this method is to estimate EPO regional phase PCT applications on the basis of the past behaviour of the data series. Although ARIMA models are used for estimating data, they might be more suitable for a forecasting exercise than a nowcasting exercise. This is because as mentioned above the amount of information available for the forecasting exercise is limited compared to the nowcasting exercise. Hence, for the forecasting exercise one needs to rely on the past trend of the data series. Whereas in the nowcasting exercise additional available information, i.e. EPO designated PCT applications, could be useful in estimating the EPO regional phase PCT data series, these can not taken into consideration by the AR and MA model (at least in this case).

\section{Method E}

This model is similar to method D. The difference between this method and method D is that rather than estimating the EPO regional phase PCT applications and adding them to direct EPO applications to obtain the total number of EPO patent applications, total EPO patent applications are estimated using a country specific AR(1) or MA(1) model. Similar to method D, this method does not take into consideration the latest developments in EPO designated PCT applications and direct EPO applications. For this reason, the prior expectation is that this method will not improve on the result achieved by the other methods. The formula for this method is the same as the one used for method D, but the Xt now represents the log first difference of total EPO patent applications.

To identify a suitable model to nowcast EPO patent applications data, an "estimation sample" data is used to nowcast 1997-99 data points. The estimated number of total EPO patent applications (i.e. results from the five methods) and the actual data are reported in Table A9. The mean absolute percentage error 
(MAPE) is used to test the predictive power of each method. MAPE is the percentage difference between the estimated and actual values.

$$
M A P E=\frac{1}{h+1} \sum_{s}^{s+h}\left|\frac{T E P O_{t}-T E P O_{t}}{T E P O_{t}}\right|
$$

where $h$ is the number of periods for the forecast, $T \hat{E} P O_{t}$ is the estimated number of EPO patent applications for time period $\mathrm{t}$ and $T E P O_{t}$ is the actual number of EPO patent applications for period $\mathrm{t}$.

\section{Nowcasting results}

The two-year and three-year MAPE statistics relate to the nowcast periods 1997-98 and 1997-99, respectively. A large difference between the estimated data and the actual data will produce large MAPE statistics, and vice versa. Hence the method with the smallest MAPE value is preferable, as it has better predictive power. Methods A and B outperform methods C, D and E (Table 2). For the two-year nowcast, method A produces low MAPE statistics for eight countries plus the EU zone total, whereas method B produces low MAPE statistics for nine countries plus the OECD zone total. For the five large patenting countries, the United States has low MAPE statistics under method A; Japan has a low MAPE value under method B; and no difference between method A and method B for France, Germany and the United Kingdom. There is little difference between method A and method B for the two-year nowcast exercise.

Similarly, there is little difference between methods A and B for the three-year nowcast. Method A produces low MAPE statistics for ten countries, (Table 2), whereas method B produces small MAPE statistics for 16 countries. For the five large patenting countries, the United States has low MAPE statistics under method A; and Germany has low MAPE statistics under method B.

As the difference between method A and method B is relatively small, the total number of EPO patent applications for 1999 and 2000 is estimated using both method A and method B. The estimated data is reported along with the 1999 and 2000 actual data, which are partial at the moment (Table 3). The total number of EPO patent applications filed by the OECD countries is estimated to be around 104667 (1999) and 115492 (2000) under method A, and 104461 (1999) and 115222 (2000) under method B. The partial 1999 and 2000 data shows the number of EPO patent application to be around 100929 and 107045 , respectively. However, this number is certain to increase as EPO designated PCT applications enter the EPO regional phase at the end of the legal time limit (31 months from the priority date).

As shown above, using the previous year(s) ratio of EPO regional phase PCT applications to EPO designated PCT applications, it is possible to estimate the number of EPO designated PCT applications that will enter the EPO regional phase. This information then can be used to estimate the total number of EPO patent applications and improve the timelines of the EPO patent data. 
Table 2. Mean absolute percentage error (MAPE) statistics

\begin{tabular}{|c|c|c|c|c|c|c|c|c|c|c|}
\hline & \multicolumn{5}{|c|}{2 Years Method } & \multicolumn{5}{|c|}{3 Years Method } \\
\hline & $\mathbf{A}$ & B & C & D & $\mathbf{E}$ & $\mathbf{A}$ & B & C & D & $E$ \\
\hline Australia & 7.5 & 4.2 & 6.8 & 17.8 & 17.9 & 10.2 & 6.5 & 9.8 & 26.5 & 26.8 \\
\hline Austria & 1.0 & 1.5 & 1.4 & 2.8 & 12.3 & 1.6 & 2.2 & 2.2 & 3.8 & 14.5 \\
\hline Belgium & 0.8 & 0.8 & 1.0 & 4.4 & 11.7 & 1.0 & 0.9 & 1.8 & 7.7 & 12.3 \\
\hline Canada & 2.1 & 1.5 & 0.3 & 25.9 & 13.3 & 1.9 & 1.7 & 2.2 & 42.4 & 16.1 \\
\hline Czech Republic & 2.4 & 5.8 & 8.9 & .. & .. & 4.3 & 4.4 & 10.1 & .. & .. \\
\hline Denmark & 1.8 & 1.2 & 0.3 & 7.5 & 3.3 & 2.1 & 1.4 & 0.7 & 8.7 & 2.6 \\
\hline Finland & 0.8 & 0.8 & 2.9 & 6.5 & 4.0 & 0.6 & 1.2 & 3.9 & 8.5 & 6.1 \\
\hline France & 0.5 & 0.5 & 0.5 & 1.2 & 6.0 & 0.5 & 0.5 & 1.2 & 1.1 & 7.8 \\
\hline Germany & 0.2 & 0.2 & 0.4 & 0.9 & 1.8 & 0.7 & 0.6 & 1.2 & 1.3 & 3.0 \\
\hline Greece & 4.8 & 3.5 & 2.2 & .. & .. & 6.5 & 5.0 & 3.0 & .. & .. \\
\hline Hungary & 12.7 & 11.8 & 11.2 & .. & 9.7 & 10.6 & 11.5 & 12.3 & .. & 19.8 \\
\hline Iceland & 26.5 & 19.7 & 15.0 & .. & .. & 20.7 & 18.7 & 19.8 & .. & .. \\
\hline Ireland & 1.5 & 1.6 & 2.5 & .. & 5.8 & 2.6 & 3.2 & 4.9 & .. & 7.9 \\
\hline Italy & 0.4 & 0.4 & 0.5 & 0.5 & 2.0 & 0.4 & 0.3 & 0.5 & 1.0 & 3.4 \\
\hline Japan & 0.4 & 0.2 & 0.5 & 1.0 & 1.1 & 0.5 & 0.4 & 0.4 & 1.6 & 2.2 \\
\hline Korea & 5.9 & 1.7 & 3.7 & 12.3 & 18.3 & 5.5 & 4.8 & 4.5 & 14.8 & 18.5 \\
\hline Luxembourg & 1.8 & 1.9 & 1.7 & .. & 27.0 & 2.6 & 2.5 & 2.9 & .. & 30.7 \\
\hline Mexico & 20.1 & 10.0 & 18.5 & .. & .. & 20.4 & 8.4 & 25.3 & .. & .. \\
\hline Netherlands & 0.8 & 0.4 & 2.1 & 20.2 & 1.5 & 0.6 & 0.5 & 3.4 & 29.2 & 4.3 \\
\hline New Zealand & 3.1 & 7.4 & 12.7 & .. & 17.3 & 6.0 & 10.7 & 17.2 & .. & 23.0 \\
\hline Norway & 0.9 & 1.0 & 0.1 & 5.8 & 5.5 & 1.4 & 0.7 & 0.7 & 8.0 & 6.0 \\
\hline Poland & 25.3 & 10.7 & 44.0 & .. & .. & 41.7 & 22.2 & 74.6 & .. & .. \\
\hline Portugal & 5.5 & 5.7 & 5.7 & .. & .. & 7.0 & 7.6 & 7.6 & .. & .. \\
\hline Slovak Republic & 14.6 & 21.3 & .. & .. & .. & 17.1 & 24.3 & .. & .. & .. \\
\hline Spain & 1.2 & 0.7 & 1.1 & 3.0 & 8.1 & 2.5 & 1.4 & 2.7 & 4.8 & 10.1 \\
\hline Sweden & 1.2 & 1.5 & 3.5 & 2.2 & 2.7 & 2.5 & 2.9 & 5.6 & 4.1 & 2.9 \\
\hline Switzerland & 1.4 & 1.2 & 2.4 & 1.3 & 9.1 & 1.5 & 1.3 & 3.1 & 1.7 & 12.1 \\
\hline Turkey & 8.7 & 2.4 & .. & .. & .. & 30.0 & 18.9 & .. & .. & .. \\
\hline United Kingdom & 0.3 & 0.3 & 0.9 & 1.6 & 5.4 & 1.0 & 1.0 & 2.3 & 1.4 & 8.6 \\
\hline United States & 0.2 & 0.6 & 0.9 & 2.8 & 3.3 & 2.0 & 2.6 & 3.2 & 5.2 & 3.8 \\
\hline EU & 0.0 & 0.1 & 0.8 & 1.2 & 3.5 & 0.5 & 0.5 & 1.7 & 2.6 & 5.1 \\
\hline OECD & 0.3 & 0.1 & 0.4 & 1.4 & 3.2 & 1.0 & 1.0 & 1.5 & 2.8 & 4.7 \\
\hline
\end{tabular}

Source: OECD, Patent Database, November 2003. 
Table 3. Number of EPO patent applications (direct EPO applications + EPO regional phase PCT applications), 1999-2000

\begin{tabular}{|c|c|c|c|c|c|c|c|c|c|}
\hline & \multicolumn{3}{|c|}{ Actual Complete } & \multicolumn{2}{|c|}{$\begin{array}{c}\text { Available } \\
\text { Partial data }\end{array}$} & \multicolumn{2}{|c|}{ Method A estimates } & \multicolumn{2}{|c|}{ Method B estimates } \\
\hline & 1996 & 1997 & 1998 & 1999 & 2000 & 1999 & 2000 & 1999 & 2000 \\
\hline Australia & 399 & 504 & 563 & 821 & 858 & 757 & 872 & 758 & 873 \\
\hline Austria & 651 & 808 & 818 & 861 & 1015 & 878 & 1010 & 878 & 1010 \\
\hline Belgium & 707 & 909 & 934 & 971 & 956 & 975 & 996 & 989 & 1011 \\
\hline Canada & 905 & 1215 & 1332 & 1519 & 1471 & 1612 & 1659 & 1593 & 1636 \\
\hline Czech Republic & 24 & 30 & 48 & 46 & 46 & 53 & 47 & 51 & 45 \\
\hline Denmark & 579 & 577 & 695 & 737 & 825 & 739 & 882 & 738 & 881 \\
\hline Finland & 899 & 1096 & 1251 & 1566 & 1557 & 1530 & 1614 & 1546 & 1630 \\
\hline France & 5413 & 6122 & 6569 & 7058 & 7062 & 7197 & 7377 & 7144 & 7316 \\
\hline Germany & 15136 & 17080 & 18857 & 20156 & 21280 & 20511 & 21970 & 20575 & 22042 \\
\hline Greece & 31 & 48 & 56 & 48 & 45 & 47 & 49 & 46 & 48 \\
\hline Hungary & 50 & 56 & 38 & 79 & 58 & 55 & 51 & 66 & 61 \\
\hline Iceland & 10 & 8 & 10 & 19 & 26 & 10 & 16 & 14 & 21 \\
\hline Ireland & 140 & 161 & 200 & 230 & 214 & 250 & 232 & 244 & 226 \\
\hline Italy & 2516 & 2791 & 2922 & 3269 & 3473 & 3253 & 3462 & 3275 & 3488 \\
\hline Japan & 13764 & 14611 & 15313 & 17737 & 20399 & 18036 & 21420 & 17969 & 21331 \\
\hline Korea & 467 & 629 & 893 & 990 & 1219 & 1197 & 1786 & 1164 & 1729 \\
\hline Luxembourg & 107 & 117 & 144 & 133 & 138 & 144 & 158 & 140 & 154 \\
\hline Mexico & 8 & 29 & 23 & 25 & 19 & 31 & 35 & 28 & 32 \\
\hline Netherlands & 2445 & 2670 & 2926 & 3363 & 3840 & 3377 & 3868 & 3401 & 3897 \\
\hline New Zealand & 74 & 90 & 97 & 129 & 136 & 115 & 138 & 116 & 139 \\
\hline Norway & 280 & 306 & 329 & 353 & 362 & 347 & 355 & 348 & 357 \\
\hline Poland & 15 & 19 & 22 & 23 & 24 & 29 & 38 & 31 & 41 \\
\hline Portugal & 20 & 23 & 25 & 35 & 39 & 35 & 45 & 40 & 50 \\
\hline Slovak Republic & 6 & 11 & 8 & 12 & 6 & 10 & 12 & 12 & 15 \\
\hline Spain & 357 & 486 & 491 & 602 & 624 & 581 & 618 & 573 & 610 \\
\hline Sweden & 1906 & 2179 & 2243 & 2421 & 2507 & 2554 & 2861 & 2527 & 2831 \\
\hline Switzerland & 2393 & 2716 & 3023 & 3258 & 3546 & 3284 & 3610 & 3272 & 3595 \\
\hline Turkey & 12 & 15 & 26 & 19 & 34 & 34 & 44 & 33 & 42 \\
\hline United Kingdom & 3477 & 3706 & 4131 & 4476 & 4653 & 4655 & 4978 & 4637 & 4958 \\
\hline United States & 23678 & 26033 & 28366 & 29972 & 30612 & 32372 & 35286 & 32254 & 35150 \\
\hline EU & 34384 & 38774 & 42265 & 45925 & 48228 & 46725 & 50122 & 46753 & 50153 \\
\hline OECD & 76469 & 85047 & 92356 & 100929 & 107045 & 104667 & 115492 & 104461 & 115222 \\
\hline
\end{tabular}

Source: OECD, Patent Database, November 2003.

\section{Conclusion}

Since the mid-1980s, the Patent Cooperation Treaty procedure has become a popular method for filing patent applications. The total number of EPO designated PCT applications (based on priority date) in 2000 amounted to around 102 836, a significant increase from the 1986 level of around 7 837. Although the PCT procedure is used by a large number of countries across the world, a small number of countries accounts for the majority of the total EPO designated PCT applications: France, Germany, Japan, the United Kingdom and the United States account for around three-quarters of the total.

This paper shows that the decision on whether to include or exclude PCT data has a significant impact on EPO patent statistics. If the purpose is to obtain an accurate measure of the total number of EPO patent applications and to use this information to measure innovative activities, then it is recommended that EPO regional phase PCT data should be taken into consideration when calculating the total number of EPO 
patent applications. This recommendation is based on the following observations: a) EPO regional phase PCT applications account for more than half of total EPO patent applications; $b$ ) filtering out the EPO designated PCT applications which do not enter the EPO regional phase will limit the overestimation of EPO patent statistics; and $c$ ) the grant rate of EPO regional phase PCT applications is comparable to the grant rate of direct EPO applications, as a consequence, comparability of EPO patent statistics is enhanced.

A major drawback of including EPO regional phase PCT data in EPO patent statistics is that it will lead to a deterioration in the timeliness of EPO patent statistics. This is due to the legal time lag between priority date and entry of PCT application in the EPO regional phase (up to 31 months). However, as shown in this paper, it is possible to improve the timeliness of EPO patent statistics by nowcasting the number of EPO regional phase PCT applications.

The decision to advocate a filter to exclude EPO designated PCT applications which do not enter the EPO regional phase is determined by the phenomena that are to be measured. From a science and technology (S\&T) policy perspective, patent indicators are viewed as a key measure of innovative output. Therefore, our intention is to develop internationally comparable patent indicators that can be used, in combination with other S\&T indicators, to address various policy issues. For this purpose, advocating a filter to exclude EPO designated PCT applications which do not enter the EPO regional phase is deemed to be appropriate. Nevertheless, statistics on all PCT applications should be collected, because they are useful for the nowcasting exercise and addressing other issues. 


\section{ANNEX A: THE PATENT COOPERATION TREATY (PCT)}

The Patent Cooperation Treaty (PCT) was signed in 1970 and entered into force in 1978. The increasing level of acceptance of the PCT for multinational patent filings is reflected by a growing number of countries being party to the treaty: currently there are 123 member countries (January 2004) compared to 20 in 1978. The PCT procedure streamlined the process for multi-nation patent filings. It provides the possibility to seek patent rights in a large number of countries by filing a single international application (PCT application) with a single patent office (receiving office). However, it should be noted that PCT applications do not result in the issuance of "international patents". The decision on whether to grant or reject patent rights rests with national or regional patent offices and the rights are limited to the territory under the governing authority's jurisdiction. The PCT procedure consists of two main phases: $a$ ) an international phase, and $b$ ) a national/regional phases. ${ }^{15}$ The application process starts during the international phase and concludes with the national/regional phase. Rules and regulations governing PCT procedure are continuously updated. In this paper, rules and regulations that are effective up to 2002 are taken into consideration because of the data coverage (up to 2002). However, Box A and Box B highlight some of the significant changes in the PCT procedure that came into effect in January 2004.

\section{International phase}

The international phase of the PCT consists of two chapters: Chapter I and Chapter II. Each PCT application starts with the Chapter I process. Applicants have the option of invoking the Chapter II process within the legal time limit (i.e. Chapter I is compulsory and Chapter II is optional).

The PCT process starts with the filing of the PCT application ${ }^{16}$ at the receiving office. In the application form, the applicant "designates" the countries where patent rights are being sought (see Box A for details on designating countries). This is the start of the Chapter I process. Each PCT application is subject to an international search of the prior art that are relevant to the patentability of the inventions. One of the appointed International Searching Authorities (ISA) undertakes the international search. ${ }^{17}$ The ISA issues an international search report (ISR), which contains the citations of the documents considered to be relevant, the classification of the subject matter of the invention and an indication of the fields searched (including electronic database). The ISR is made available to the applicant within 16 months of the priority date. The International Bureau publishes the PCT application and the ISR 18 months after the priority date.

At the expiry date of the Chapter I process (19 months), applicants have the possibility to file a "demand" for International Preliminary Examination (IPE). This is commonly referred to as the Chapter II

15. This phase is commonly referred to as the "national phase", even when the international application is transferred to a regional patent office, such as the EPO.

16. In the majority of cases, applicants file for domestic patent rights at the national patent office in the first instance, followed by a PCT application (within 12 months to claim the priority rights of the domestic filing) for foreign patent rights.

17. The latest available data show that the EPO is selected by $56 \%$ of the applicants to act as ISA, compared to $23 \%$ for the USPTO and $11 \%$ for JPO. 
process. The demand for IPE should be filed within 19 months of the priority date. After receiving the demand for IPE and the ISR, the International Preliminary Examination Authority (IPEA) starts the process to establish an international preliminary examination report (IPER) ${ }^{18}$ which is established within 28 months of the priority date. The IPER provides a non-binding opinion on the patentability of the claimed invention (i.e. whether the claimed invention appears to be novel, to involve an inventive step and to be industrially applicable).

\section{Box A: "Designation of countries"}

To obtain national patents, applicants have to designate (in the application) each PCT member country where patent rights are being sought. Similarly, for obtaining regional patents (e.g. EPO), applicants have to indicate the appropriate patent office where patents are being sought. Several European countries (e.g. France, Greece, Italy, the Netherlands, etc.) can only be designated for a European patent (i.e. they can not be designated for national patents) since only a European patent can be obtained via the PCT procedure.

With a single PCT application, applicants have the possibility of seeking patent rights (by designating the countries) in all the PCT countries. The decision on the number of countries to be designated is determined by the patenting strategies of the applicants and the designation costs. During 2002-03, applicants had to pay designation fees for only the first five designated countries. ${ }^{19}$ As designating more than five countries did not increase the total designation costs, applicants have the incentive to cover maximum possible designation. This is reflected in the statistics published by the WIPO (World Intellectual Property Organisation). In 2002, the average number of countries designated per PCT application was $119^{20}$ and $81.4 \%$ of the total PCT applications consisted of paying the maximum designation fees (i.e. the first five countries) while covering the maximum possible number of designations.

New designation system: effective from January 2004, applicants will obtain automatic and all-inclusive coverage of all designations available under the PCT at the time of the PCT application. It is no longer possible to exclude any countries from being designated except for Germany, Korea and Russia as these countries have national laws stipulating the automatic withdrawal of national applications from which priority is claimed. Designation countries can be withdrawn at a later date.

18. The latest available data shows that around $80 \%$ of the total PCT application request IPER. The EPO and the USPTO are selected by respectively $51 \%$ and $30 \%$ of the applicants to act as the IPEA.

19. In recent years, there has been a continuous reduction in the maximum number of designation fees payable. In 2002, the maximum number of designation fees payable was reduced to five, compare to six in 2001, eight in 2000, and ten in 1999. As of January 2004, applicants pay a single international fee which covers the designation of all countries.

20. The average number of designation states per PCT application is higher than the total number of PCT contracting states due to double counting of national and regional designations. 


\section{Box B: Changes to the International phase rules effective from 2004}

Rule change for the Chapter I process: under the new international search and preliminary examination system, in addition to the ISR, the ISA will establish a written opinion for every single PCT application filed on or after January 2004. The International Bureau will publish the PCT application and the ISR 18 months after the priority date. However, the written opinion of the ISA will not be published. If the applicant does not file a demand for International Preliminary Examination (Chapter II process, see below), the written opinion established by the ISA will be converted into an International Preliminary Report on Patentability (IPRP, Chapter I).

Rule change for the "election of states": it is no longer possible to exclude any countries ${ }^{21}$ from being elected (i.e. filing of a demand for IPE will constitute the election of all the PCT countries).

New time limit for filing a demand for IPE: the new time limit for filing a demand for IPE is 22 months from the priority date (or three months after the issuance of the ISA and the written opinion of the ISA).

The written opinion established by the ISA will in general be used by the IPEA as its own opinion, unless the IPEA notifies the International Bureau to the contrary. Within 28 months of the priority date, the IPEA will issue an international preliminary examination report called International Preliminary Report on Patentability (IPRP, Chapter II).

The introduction of the new international search and preliminary examination system has elevated the status of the Chapter I process. An IPRP will be produced for every single PCT application filed. The main difference between the Chapter I and Chapter II process is that under Chapter I, there is no dialogue or amendments between the applicant and the ISA before the issuance of IPRP. Under Chapter II, the applicant has the right to file amendments (to the descriptions, drawings and claims) and arguments concerning the written opinion of the ISA before the issuance of the IPRP.

\section{National/regional phase}

After the international phase, if applicants still wish to proceed to seek patent rights, PCT applications have to proceed to the national/regional phase. PCT applications do not automatically enter the national/regional phase. It is up to the applicants to decide whether to proceed. To invoke the national/regional phase process, applicants have to pay the national fees for each designated office, and where necessary provide a copy of the PCT application and a translation. During the national/regional phase, PCT applications are processed by the designated patent office(s) to decide whether to grant patent rights. In each designated country, PCT applications are treated as a national (or regional) application and the decision to grant or reject patent rights rests with the national (or regional) patent office. The decision on the entry to the national phase can be delayed up to 30 months ( 31 months in the case of the EPO regional phase) under Chapter II process and 20 months under Chapter I process. follows:

Of PCT applications filed before April 2002, the time limits for entering the national phase were as

a) Within 20 months of the priority date if the applicants do not file a demand for international preliminary examination (i.e. applicants did not invoke the Chapter II process); or

b) Within 30 months (31 months in the case of EPO) of the priority date when the applicants file a demand for international preliminary examination (i.e. applicants invoke the Chapter II process).

Rules relating to the time limit for entering the national/regional phase were modified in April 2002. The new time limit for entering the national/regional phase is 30 months ( 31 months for EPO regional

21. It is possible to explicitly refrain from designating Germany, Korea and Russia, as these countries have national laws stipulating the automatic withdrawal of national applications from which priority is claimed. See Box A. 
phase) under both Chapter I and Chapter II processes, irrespective of whether or not the applicants file a "demand" for international preliminary examination. The consequence of the rule change is that for all PCT applications, the decision on whether to proceed to the national phase can be postponed up to 30 months (31 months, EPO) from the priority date. The time limits of various stages of the PCT procedure are presented in Figure A1.

Figure A1. Time limits of the PCT procedure (since April 2002)

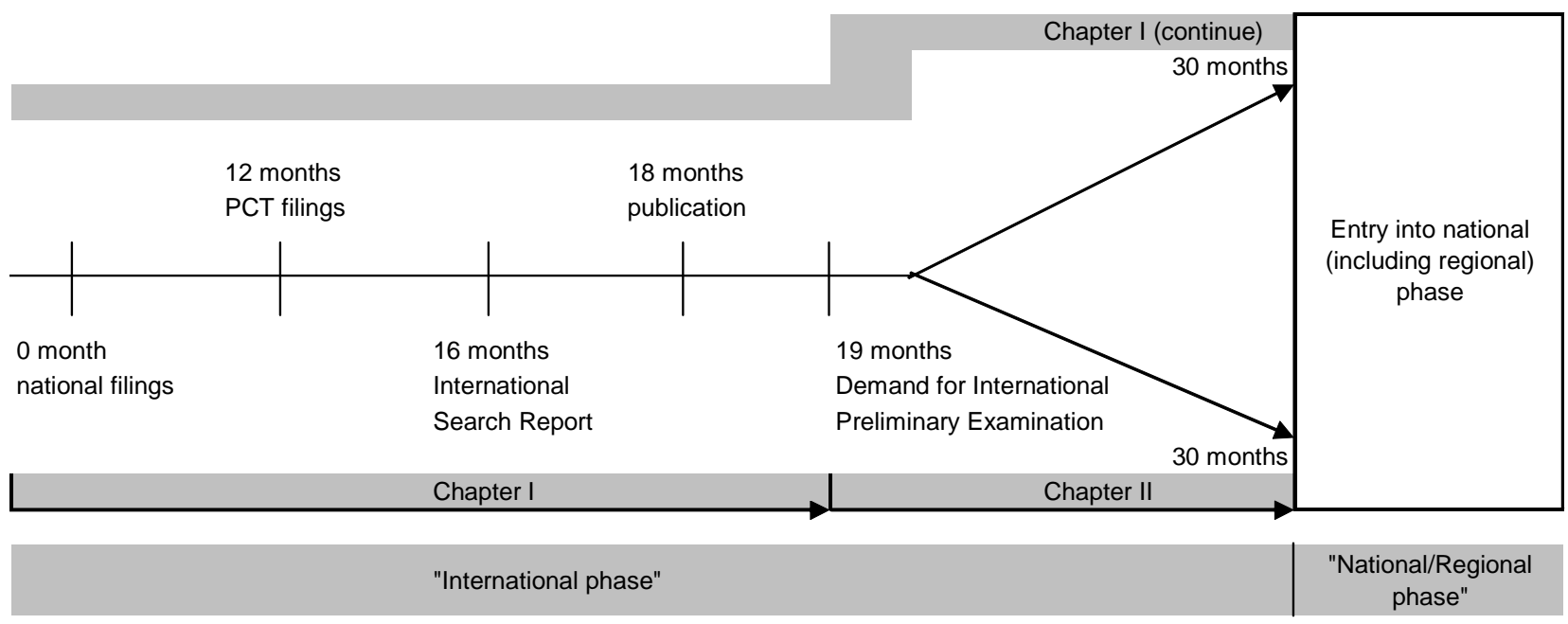

Note: The time limit for filing a demand for international preliminary examination is extended from 19 months to 22 months from the priority date or three months from the date of transmittal of the ISR and the written opinion of the ISA (effective from January 2004).

\section{Main advantages of the PCT procedure}

A major advantage of the PCT system is that a substantial proportion of the foreign filing costs can be deferred up to 30 months (31 months for the EPO regional phase) from the priority date, compared to 12 months allowed under the Paris Convention. It is important to note that the total costs of patenting in foreign countries is deferred and not avoided, because if the applicant proceeds to the national/regional phase, costs have to be borne by the applicant. Although the total cost of a PCT application can be substantial, it is considerably less than the total cost of direct applications to various foreign countries. ${ }^{22}$ The total cost of a PCT application during the international phase is estimated to be around USD 4000 to USD $9000 .^{23}$ The official PCT application fees for the international phase, excluding the patent attorney fees, are however much lower: approximately USD $2511^{24}$ to USD $3440 .{ }^{25}$ The indicated fee structure

22. For example, protecting inventions in North America, Japan, Europe, Australia and a few other countries is estimated to cost around CAD 50000 (see, Armstrong \& Associates, www.canpat.com).

23. The average cost of a PCT application is estimated to be around USD 9000 (including the patent attorney fees) for the international phase (see, Armstrong \& Associates, www.canpat.com). Brown \& Michaels (www.bpmlegal.com) estimates the cost of a PCT application to be around USD 4000 for the international phase.

24. In the case of the USPTO being selected as the ISA and IPEA, the total official cost of a PCT application (USD 2 511) will include the following: transmittal fee (USD 240), basic fee (USD 407), designation fee (USD 528 for five designation countries), search fee (USD 700), preliminary examination fee (USD 490), and handling fee (USD 146). The total cost indicated here should be treated as a rough guide, because fees tend to vary according to the length of the patent document (e.g. extra fees per sheet in excess of 30 sheets) and the status of the patent applicant (e.g. reductions are available for applicants from certain countries). 
reflects the situation during the late 1990s. In recent years, there have been significant changes to the fee structure.

- The PCT system allows the applicant to spread the costs of patenting over a 30-month (31-month for EPO regional phase) period. Applicants do not have to pay all the costs at the time of filing. For example, at the time of a PCT application, applicants are required to pay the basic fees. The IPE fee becomes payable at the time of filing the demand for IPE (around 19 months from the priority date). Designation fees and translation costs are due when the PCT application is transferred to the national phase.

- Apart from the cost advantage, the PCT procedure allows the applicant to defer the decision on whether to proceed with foreign filings by an additional 18 months in order to claim the earliest priority date (under the Paris Convention, applicants have up to 12 months). The additional 18 months can be very useful for the applicant to assess and test the commercialisation prospects of the invention before incurring considerable costs associated with the national phase.

- Furthermore, the PCT application automatically results in an international search report and the applicant can also request an international preliminary examination report. Both of those reports provide additional information on the patentability of the invention and the applicant is in a better position to decide whether it is worthwhile to incur the costs associated with the national phase.

25. In the case of the EPO being selected as the ISA \& IPEA, the total official cost of a PCT application (USD 3 440) will include the following: transmittal fee (USD 94), basic fee (USD 418), designation fee (USD 452 for 5 designation countries), search fee (USD 889), preliminary examination fee (USD 1439 ), and handling fee (USD 150). The 2002 EUR to USD exchange rate (1.063) is used to convert the fees from EUR to USD. 
ANNEX TABLES

Table A1. Estimated number of EPO designated PCT applications (priority date)

\begin{tabular}{|c|c|c|c|c|c|c|c|c|c|}
\hline & \multicolumn{5}{|c|}{ Number of applications } & \multicolumn{2}{|c|}{$\begin{array}{l}\text { Average annual } \\
\text { growth rate }\end{array}$} & \multicolumn{2}{|c|}{ Country shares } \\
\hline & 1986 & 1990 & 1995 & 1998 & 2000 & 1986-1998 & $1986-2000$ & 1998 & 2000 \\
\hline Australia & 399 & 554 & 788 & 1078 & 1675 & 8.6 & 10.8 & 1.5 & 1.6 \\
\hline Austria & 83 & 154 & 357 & 426 & 655 & 14.6 & 15.9 & 0.6 & 0.6 \\
\hline Belgium & 19 & 122 & 266 & 475 & 634 & 30.7 & 28.4 & 0.7 & 0.6 \\
\hline Canada & 24 & 472 & 954 & 1390 & 2083 & 40.3 & 37.6 & 1.9 & 2.0 \\
\hline Czech Republic & 0 & 5 & 22 & 61 & 72 & .. & .. & 0.1 & 0.1 \\
\hline Denmark & 135 & 335 & 561 & 702 & 884 & 14.7 & 14.4 & 1.0 & 0.9 \\
\hline Finland & 145 & 355 & 648 & 1262 & 1554 & 19.8 & 18.5 & 1.8 & 1.5 \\
\hline France & 354 & 998 & 2027 & 3373 & 4479 & 20.7 & 19.9 & 4.7 & 4.4 \\
\hline Germany & 917 & 2585 & 5755 & 10209 & 13458 & 22.2 & 21.2 & 14.2 & 13.1 \\
\hline Greece & 0 & 15 & 25 & 45 & 44 & .. & .. & 0.1 & 0.0 \\
\hline Hungary & 54 & 55 & 74 & 91 & 126 & 4.4 & 6.2 & 0.1 & 0.1 \\
\hline Iceland & 1 & 1 & 8 & 19 & 33 & 35.4 & 34.9 & 0.0 & 0.0 \\
\hline Ireland & 0 & 10 & 123 & 177 & 229 & .. & .. & 0.2 & 0.2 \\
\hline Italy & 133 & 271 & 617 & 1031 & 1536 & 18.6 & 19.1 & 1.4 & 1.5 \\
\hline Japan & 781 & 1568 & 3258 & 6068 & 10616 & 18.6 & 20.5 & 8.5 & 10.3 \\
\hline Korea & 17 & 40 & 241 & 754 & 1952 & 37.2 & 40.3 & 1.1 & 1.9 \\
\hline Luxembourg & 6 & 6 & 53 & 116 & 129 & 28.9 & 25.3 & 0.2 & 0.1 \\
\hline Mexico & 0 & 2 & 23 & 47 & 81 & .. & 0.0 & 0.1 & 0.1 \\
\hline Netherlands & 67 & 316 & 1504 & 2292 & 3364 & 34.2 & 32.3 & 3.2 & 3.3 \\
\hline New Zealand & 1 & 10 & 130 & 216 & 290 & 56.5 & 49.9 & 0.3 & 0.3 \\
\hline Norway & 66 & 169 & 334 & 447 & 531 & 17.3 & 16.1 & 0.6 & 0.5 \\
\hline Poland & 0 & 10 & 18 & 46 & 96 & .. & .. & 0.1 & 0.1 \\
\hline Portugal & 0 & 1 & 13 & 16 & 31 & .. & .. & 0.0 & 0.0 \\
\hline Slovak Republic & 0 & 0 & 16 & 19 & 32 & .. & .. & 0.0 & 0.0 \\
\hline Spain & 0 & 76 & 257 & 397 & 535 & .. & .. & 0.6 & 0.5 \\
\hline Sweden & 545 & 842 & 1711 & 2607 & 3275 & 13.9 & 13.7 & 3.6 & 3.2 \\
\hline Switzerland & 219 & 394 & 1048 & 1591 & 2241 & 18.0 & 18.1 & 2.2 & 2.2 \\
\hline Turkey & 0 & 0 & 5 & 45 & 77 & .. & .. & 0.1 & 0.1 \\
\hline United Kingdom & 697 & 2036 & 2865 & 3969 & 5266 & 15.6 & 15.5 & 5.5 & 5.1 \\
\hline United States & 3028 & 9332 & 19512 & 30050 & 41719 & 21.1 & 20.6 & 41.9 & 40.6 \\
\hline European Union & 3101 & 8125 & 16782 & 27098 & 36076 & 19.8 & 19.2 & 37.8 & 35.1 \\
\hline OECD & 7690 & 20736 & 43213 & 69020 & 97700 & 20.1 & 19.9 & 96.3 & 95.0 \\
\hline Total & 7837 & 21041 & 44329 & 71670 & 102836 & 20.3 & 20.2 & 100.0 & 100.0 \\
\hline
\end{tabular}

Source: OECD, Patent Database, November 2003. 


\section{DSTI/DOC(2005)2}

Table A2. Direct EPO applications (i.e. applications filed at the EPO without the use of the PCT procedure)

\begin{tabular}{|c|c|c|c|c|c|c|c|}
\hline & \multicolumn{5}{|c|}{ Number of applications } & \multirow{2}{*}{$\begin{array}{c}\text { Average annual } \\
\text { growth rate } \\
1986-2000 \\
\end{array}$} & \multirow{2}{*}{$\begin{array}{c}\text { Country } \\
\text { shares } \\
2000 \\
\end{array}$} \\
\hline & 1986 & 1990 & 1995 & 1998 & 2000 & & \\
\hline Australia & 124 & 69 & 33 & 35 & 51 & -7.2 & 0.1 \\
\hline Austria & 397 & 500 & 316 & 504 & 528 & 2.4 & 1.1 \\
\hline Belgium & 369 & 340 & 452 & 557 & 493 & 2.5 & 1.0 \\
\hline Canada & 413 & 245 & 179 & 424 & 299 & -2.6 & 0.6 \\
\hline Czech Republic & 15 & 19 & 4 & 20 & 14 & -0.3 & 0.0 \\
\hline Denmark & 123 & 105 & 94 & 170 & 220 & 4.9 & 0.5 \\
\hline Finland & 109 & 208 & 267 & 337 & 487 & 13.3 & 1.0 \\
\hline France & 3398 & 4092 & 3441 & 3838 & 3749 & 0.8 & 7.7 \\
\hline Germany & 8822 & 9238 & 8152 & 10755 & 11290 & 2.1 & 23.3 \\
\hline Greece & 10 & 14 & 7 & 24 & 18 & 5.0 & 0.0 \\
\hline Hungary & 47 & 35 & 8 & 5 & 4 & -18.6 & 0.0 \\
\hline Iceland & 2 & 2 & 0 & 1 & 1 & -5.6 & 0.0 \\
\hline Ireland & 42 & 54 & 30 & 72 & 65 & 3.6 & 0.1 \\
\hline Italy & 1486 & 1944 & 1792 & 2210 & 2403 & 4.1 & 5.0 \\
\hline Japan & 6718 & 11553 & 9739 & 10605 & 13184 & 5.8 & 27.2 \\
\hline Korea & 2 & 106 & 324 & 454 & 649 & 61.9 & 1.3 \\
\hline Luxembourg & 93 & 48 & 25 & 48 & 52 & -4.8 & 0.1 \\
\hline Mexico & 4 & 11 & 6 & 4 & 2 & -6.2 & 0.0 \\
\hline Netherlands & 1558 & 1653 & 929 & 1030 & 1086 & -3.0 & 2.2 \\
\hline New Zealand & 34 & 10 & 13 & 6 & 16 & -6.1 & 0.0 \\
\hline Norway & 65 & 33 & 36 & 60 & 35 & -5.0 & 0.1 \\
\hline Poland & 27 & 8 & 3 & 6 & 4 & -13.9 & 0.0 \\
\hline Portugal & 5 & 5 & 19 & 15 & 25 & 14.4 & 0.1 \\
\hline Slovak Republic & 0 & 2 & 1 & 1 & 0 & .. & 0.0 \\
\hline Spain & 128 & 187 & 186 & 275 & 325 & 8.1 & 0.7 \\
\hline Sweden & 486 & 356 & 281 & 314 & 437 & -0.9 & 0.9 \\
\hline Switzerland & 1576 & 1791 & 1326 & 1776 & 1853 & 1.4 & 3.8 \\
\hline Turkey & 2 & 3 & 1 & 2 & 3 & 3.4 & 0.0 \\
\hline United Kingdom & 2730 & 1881 & 1144 & 1313 & 1239 & -6.4 & 2.6 \\
\hline United States & 9994 & 11864 & 9617 & 9422 & 8985 & -0.9 & 18.6 \\
\hline European Union & 19755 & 20626 & 17135 & 21461 & 22417 & 1.1 & 46.3 \\
\hline OECD & 38778 & 46376 & 38425 & 44280 & 47518 & 1.7 & 98.2 \\
\hline Total & 39239 & 47021 & 38874 & 44981 & 48407 & 1.8 & 100.0 \\
\hline
\end{tabular}

Source: OECD, Patent Database, November 2003. 
Table A3. EPO regional phase PCT applications as a percentage of total EPO applications

\begin{tabular}{|c|c|c|c|c|}
\hline & 1986 & 1990 & 1995 & 1998 \\
\hline Australia & 66.7 & 78.7 & 92.1 & 93.9 \\
\hline Austria & 15.9 & 19.3 & 47.2 & 38.3 \\
\hline Belgium & 3.9 & 21.0 & 32.1 & 40.3 \\
\hline Canada & 4.1 & 50.6 & 77.0 & 68.2 \\
\hline Czech Republic & 0.0 & 11.6 & 65.9 & 58.3 \\
\hline Denmark & 42.5 & 67.8 & 80.3 & 75.6 \\
\hline Finland & 49.7 & 49.9 & 62.9 & 73.1 \\
\hline France & 7.8 & 14.5 & 31.5 & 41.6 \\
\hline Germany & 8.0 & 17.9 & 35.7 & 43.0 \\
\hline Greece & 0.0 & 39.7 & 69.6 & 56.1 \\
\hline Hungary & 48.6 & 41.7 & 80.3 & 88.3 \\
\hline Iceland & 0.0 & 20.0 & 100.0 & 89.5 \\
\hline Ireland & 0.0 & 16.2 & 75.6 & 64.2 \\
\hline Italy & 6.3 & 8.2 & 19.3 & 24.4 \\
\hline Japan & 9.1 & 10.4 & 20.4 & 30.7 \\
\hline Korea & 84.6 & 14.2 & 31.1 & 49.2 \\
\hline Luxembourg & 5.6 & 9.4 & 62.0 & 66.4 \\
\hline Mexico & 0.0 & 16.0 & 58.6 & 82.6 \\
\hline Netherlands & 3.6 & 12.6 & 57.8 & 64.8 \\
\hline New Zealand & 2.9 & 37.5 & 77.2 & 93.8 \\
\hline Norway & 41.8 & 74.9 & 85.4 & 81.9 \\
\hline Poland & 0.0 & 20.0 & 72.2 & 72.7 \\
\hline Portugal & 0.0 & 16.7 & 36.2 & 40.8 \\
\hline Slovak Republic & & 0.0 & 80.0 & 93.8 \\
\hline Spain & 0.0 & 18.8 & 44.6 & 44.1 \\
\hline Sweden & 44.2 & 61.9 & 82.1 & 86.0 \\
\hline Switzerland & 10.5 & 14.4 & 37.1 & 41.3 \\
\hline Turkey & 0.0 & 0.0 & 66.7 & 92.3 \\
\hline United Kingdom & 16.1 & 41.2 & 63.7 & 68.2 \\
\hline United States & 19.1 & 33.8 & 56.7 & 66.8 \\
\hline European Union & 10.9 & 21.7 & 42.6 & 49.2 \\
\hline OECD & 13.4 & 23.3 & 43.9 & 52.1 \\
\hline Total & 13.5 & 23.3 & 44.1 & 52.3 \\
\hline
\end{tabular}

Source: OECD, Patent Database, November 2003. 
Table A4. EPO regional phase PCT applications (priority date)

\begin{tabular}{|c|c|c|c|c|c|c|}
\hline & \multicolumn{4}{|c|}{$\begin{array}{c}\text { Number of EPO regional phase } \\
\text { PCT applications }\end{array}$} & \multirow{2}{*}{$\begin{array}{c}\text { Average annual } \\
\text { growth rate } \\
1986-1998 \\
\end{array}$} & \multirow{2}{*}{$\begin{array}{c}\text { Country } \\
\text { shares } \\
1998 \\
\end{array}$} \\
\hline & 1986 & 1990 & 1995 & 1998 & & \\
\hline Australia & 249 & 253 & 382 & 529 & 6.5 & 1.1 \\
\hline Austria & 75 & 120 & 283 & 314 & 12.6 & 0.6 \\
\hline Belgium & 15 & 91 & 214 & 377 & 30.7 & 0.8 \\
\hline Canada & 18 & 251 & 599 & 908 & 39.0 & 1.8 \\
\hline Czech Republic & 0 & 3 & 7 & 28 & .. & 0.1 \\
\hline Denmark & 91 & 220 & 384 & 526 & 15.7 & 1.1 \\
\hline Finland & 108 & 207 & 453 & 915 & 19.5 & 1.9 \\
\hline France & 289 & 694 & 1580 & 2732 & 20.6 & 5.5 \\
\hline Germany & 762 & 2019 & 4519 & 8102 & 21.8 & 16.4 \\
\hline Greece & 0 & 9 & 16 & 31 & .. & 0.1 \\
\hline Hungary & 44 & 25 & 34 & 34 & -2.2 & 0.1 \\
\hline Iceland & 0 & 1 & 5 & 9 & .. & 0.0 \\
\hline Ireland & 0 & 10 & 92 & 129 & .. & 0.3 \\
\hline Italy & 100 & 173 & 429 & 712 & 17.8 & 1.4 \\
\hline Japan & 671 & 1340 & 2497 & 4708 & 17.6 & 9.5 \\
\hline Korea & 11 & 18 & 146 & 439 & 36.0 & 0.9 \\
\hline Luxembourg & 6 & 5 & 41 & 96 & 26.9 & 0.2 \\
\hline Mexico & 0 & 2 & 9 & 19 & .. & 0.0 \\
\hline Netherlands & 59 & 239 & 1270 & 1896 & 33.6 & 3.8 \\
\hline New Zealand & 1 & 6 & 44 & 91 & 45.7 & 0.2 \\
\hline Norway & 46 & 100 & 213 & 269 & 15.8 & 0.5 \\
\hline Poland & 0 & 2 & 7 & 16 & .. & 0.0 \\
\hline Portugal & 0 & 1 & 11 & 10 & .. & 0.0 \\
\hline Slovak Republic & 0 & 0 & 4 & 8 & .. & 0.0 \\
\hline Spain & 0 & 43 & 150 & 217 & .. & 0.4 \\
\hline Sweden & 384 & 578 & 1292 & 1930 & 14.4 & 3.9 \\
\hline Switzerland & 184 & 302 & 781 & 1247 & 17.3 & 2.5 \\
\hline Turkey & 0 & 0 & 2 & 24 & .. & 0.0 \\
\hline United Kingdom & 525 & 1318 & 2008 & 2819 & 15.0 & 5.7 \\
\hline United States & 2357 & 6063 & 12617 & 18944 & 19.0 & 38.4 \\
\hline European Union & 2413 & 5727 & 12742 & 20804 & 19.7 & 42.2 \\
\hline OECD & 5995 & 14092 & 30087 & 48076 & 18.9 & 97.4 \\
\hline Total & 6126 & 14251 & 30660 & 49355 & 19.0 & 100.0 \\
\hline
\end{tabular}

Source: OECD, Patent Database, November 2003. 
Table A5. EPO regional phase PCT applications as a percentage of EPO designated PCT applications (priority date)

\begin{tabular}{|c|c|c|c|c|c|}
\hline & \multicolumn{4}{|c|}{ (\%) } & \multirow{2}{*}{$\begin{array}{c}\text { Average annua } \\
\text { growth rate } \\
1986-1998 \\
\end{array}$} \\
\hline & 1986 & 1990 & 1995 & 1998 & \\
\hline Australia & 62.5 & 45.7 & 48.5 & 49.0 & -2.0 \\
\hline Austria & 90.4 & 77.6 & 79.2 & 73.7 & -1.7 \\
\hline Belgium & 79.1 & 73.9 & 80.5 & 79.3 & 0.0 \\
\hline Canada & 73.4 & 53.2 & 62.8 & 65.3 & -1.0 \\
\hline Czech Republic & .. & 55.6 & 31.0 & 46.3 & .. \\
\hline Denmark & 67.4 & 65.7 & 68.5 & 74.9 & 0.9 \\
\hline Finland & 74.4 & 58.3 & 69.9 & 72.5 & -0.2 \\
\hline France & 81.6 & 69.5 & 77.9 & 81.0 & -0.1 \\
\hline Germany & 83.1 & 78.1 & 78.5 & 79.4 & -0.4 \\
\hline Greece & .. & 60.5 & 64.0 & 69.0 & .. \\
\hline Hungary & 81.7 & 45.5 & 45.6 & 37.4 & -6.3 \\
\hline Iceland & .. & 100.0 & 60.0 & 44.7 & .. \\
\hline Ireland & .. & 100.0 & 74.4 & 72.8 & .. \\
\hline Italy & 75.1 & 63.8 & 69.5 & 69.0 & -0.7 \\
\hline Japan & 85.9 & 85.4 & 76.6 & 77.6 & -0.8 \\
\hline Korea & 64.7 & 44.3 & 60.6 & 58.2 & -0.9 \\
\hline Luxembourg & 100.0 & 83.3 & 77.4 & 82.7 & -1.6 \\
\hline Mexico & .. & 100.0 & 37.0 & 40.9 & .. \\
\hline Netherlands & 87.3 & 75.7 & 84.4 & 82.7 & -0.5 \\
\hline New Zealand & 100.0 & 63.2 & 34.0 & 42.2 & -6.9 \\
\hline Norway & 70.3 & 59.1 & 63.7 & 60.2 & -1.3 \\
\hline Poland & .. & 20.0 & 35.1 & 35.1 & .. \\
\hline Portugal & .. & 100.0 & 84.0 & 63.3 & .. \\
\hline Slovak Republic & .. & .. & 24.5 & 38.8 & .. \\
\hline Spain & .. & 56.8 & 58.3 & 54.7 & .. \\
\hline Sweden & 70.5 & 68.6 & 75.5 & 74.0 & 0.4 \\
\hline Switzerland & 84.0 & 76.5 & 74.6 & 78.4 & -0.6 \\
\hline Turkey & .. & .. & 42.9 & 53.2 & .. \\
\hline United Kingdom & 75.2 & 64.8 & 70.1 & 71.0 & -0.5 \\
\hline United States & 77.9 & 65.0 & 64.7 & 63.0 & -1.7 \\
\hline European Union & 77.8 & 70.5 & 75.9 & 76.8 & -0.1 \\
\hline OECD & 78.0 & 68.0 & 69.6 & 69.7 & -0.9 \\
\hline Total & 78.2 & 67.7 & 69.2 & 68.9 & -1.1 \\
\hline
\end{tabular}

Source: OECD, Patent Database, November 2003. 
Table A6. Potential EPO applications (EPO designated PCT applications + direct EPO applications)

\begin{tabular}{|c|c|c|c|c|c|c|c|}
\hline & \multicolumn{5}{|c|}{ Number of applications } & \multirow{2}{*}{$\begin{array}{c}\text { Average annual } \\
\text { growth rate } \\
1986-1998\end{array}$} & \multirow{2}{*}{$\begin{array}{c}\text { Country } \\
\text { shares } \\
2000 \\
\end{array}$} \\
\hline & 1986 & 1990 & 1995 & 1998 & 2000 & & \\
\hline Australia & 523 & 622 & 821 & 1113 & 1726 & 6.5 & 1.1 \\
\hline Austria & 481 & 654 & 674 & 930 & 1183 & 5.7 & 0.8 \\
\hline Belgium & 388 & 463 & 718 & 1032 & 1127 & 8.5 & 0.7 \\
\hline Canada & 437 & 717 & 1133 & 1815 & 2382 & 12.6 & 1.6 \\
\hline Czech Republic & 15 & 24 & 25 & 81 & 86 & 15.4 & 0.1 \\
\hline Denmark & 258 & 440 & 655 & 871 & 1104 & 10.7 & 0.7 \\
\hline Finland & 254 & 563 & 915 & 1599 & 2042 & 16.6 & 1.4 \\
\hline France & 3752 & 5090 & 5469 & 7211 & 8229 & 5.6 & 5.4 \\
\hline Germany & 9738 & 11823 & 13906 & 20964 & 24748 & 6.6 & 16.4 \\
\hline Greece & 10 & 29 & 32 & 70 & 62 & 17.6 & 0.0 \\
\hline Hungary & 102 & 90 & 83 & 95 & 130 & -0.5 & 0.1 \\
\hline Iceland & 3 & 3 & 8 & 20 & 34 & 18.9 & 0.0 \\
\hline Ireland & 42 & 65 & 152 & 248 & 294 & 15.9 & 0.2 \\
\hline Italy & 1619 & 2215 & 2409 & 3242 & 3938 & 6.0 & 2.6 \\
\hline Japan & 7499 & 13121 & 12997 & 16674 & 23799 & 6.9 & 15.7 \\
\hline Korea & 19 & 146 & 565 & 1207 & 2601 & 41.3 & 1.7 \\
\hline Luxembourg & 98 & 54 & 78 & 164 & 181 & 4.4 & 0.1 \\
\hline Mexico & 4 & 13 & 29 & 51 & 83 & 22.7 & 0.1 \\
\hline Netherlands & 1625 & 1969 & 2432 & 3323 & 4450 & 6.1 & 2.9 \\
\hline New Zealand & 35 & 20 & 143 & 222 & 306 & 16.7 & 0.2 \\
\hline Norway & 130 & 203 & 370 & 507 & 566 & 12.0 & 0.4 \\
\hline Poland & 27 & 18 & 21 & 52 & 101 & 5.5 & 0.1 \\
\hline Portugal & 5 & 6 & 31 & 31 & 56 & 16.5 & 0.0 \\
\hline Slovak Republic & 0 & 2 & 17 & 20 & 32 & .. & 0.0 \\
\hline Spain & 128 & 263 & 444 & 671 & 861 & 14.8 & 0.6 \\
\hline Sweden & 1031 & 1198 & 1992 & 2921 & 3712 & 9.1 & 2.5 \\
\hline Switzerland & 1795 & 2186 & 2374 & 3367 & 4094 & 5.4 & 2.7 \\
\hline Turkey & 2 & 3 & 6 & 47 & 80 & 30.1 & 0.1 \\
\hline United Kingdom & 3427 & 3917 & 4009 & 5282 & 6505 & 3.7 & 4.3 \\
\hline United States & 13022 & 21197 & 29129 & 39472 & 50704 & 9.7 & 33.5 \\
\hline European Union & 22856 & 28750 & 33917 & 48559 & 58493 & 6.5 & 38.7 \\
\hline OECD & 46468 & 67112 & 81638 & 113300 & 145218 & 7.7 & 96.0 \\
\hline Total & 47076 & 68062 & 83203 & 116651 & 151243 & 7.9 & 100.0 \\
\hline
\end{tabular}

Source: OECD, Patent Database, November 2003. 
Table A7. Effective EPO applications (EPO regional phase PCT applications + direct EPO applications)

\begin{tabular}{|c|c|c|c|c|c|c|}
\hline & \multicolumn{4}{|c|}{ Number of applications } & \multirow{2}{*}{$\begin{array}{c}\text { Average annual } \\
\text { growth rate } \\
1986-1998\end{array}$} & \multirow{2}{*}{$\begin{array}{c}\text { Country } \\
\text { shares } \\
1998 \\
\end{array}$} \\
\hline & 1986 & 1990 & 1995 & 1998 & & \\
\hline Australia & 373 & 322 & 415 & 563 & 3.5 & 0.6 \\
\hline Austria & 473 & 620 & 599 & 818 & 4.7 & 0.9 \\
\hline Belgium & 384 & 431 & 666 & 934 & 7.7 & 1.0 \\
\hline Canada & 431 & 496 & 778 & 1332 & 9.9 & 1.4 \\
\hline Czech Republic & 15 & 22 & 10 & 48 & 10.5 & 0.1 \\
\hline Denmark & 214 & 325 & 478 & 695 & 10.3 & 0.7 \\
\hline Finland & 217 & 415 & 720 & 1251 & 15.7 & 1.3 \\
\hline France & 3687 & 4786 & 5021 & 6569 & 4.9 & 7.0 \\
\hline Germany & 9584 & 11257 & 12671 & 18857 & 5.8 & 20.0 \\
\hline Greece & 10 & 23 & 23 & 56 & 15.4 & 0.1 \\
\hline Hungary & 91 & 60 & 42 & 38 & -7.0 & 0.0 \\
\hline Iceland & 2 & 3 & 5 & 10 & 13.9 & 0.0 \\
\hline Ireland & 42 & 65 & 121 & 200 & 13.8 & 0.2 \\
\hline Italy & 1586 & 2117 & 2221 & 2922 & 5.2 & 3.1 \\
\hline Japan & 7389 & 12893 & 12236 & 15313 & 6.3 & 16.2 \\
\hline Korea & 13 & 124 & 470 & 893 & 42.3 & 0.9 \\
\hline Luxembourg & 98 & 53 & 66 & 144 & 3.3 & 0.2 \\
\hline Mexico & 4 & 13 & 15 & 23 & 14.9 & 0.0 \\
\hline Netherlands & 1616 & 1892 & 2198 & 2926 & 5.1 & 3.1 \\
\hline New Zealand & 35 & 16 & 57 & 97 & 8.9 & 0.1 \\
\hline Norway & 111 & 134 & 249 & 329 & 9.5 & 0.3 \\
\hline Poland & 27 & 10 & 9 & 22 & -1.7 & 0.0 \\
\hline Portugal & 5 & 6 & 29 & 25 & 14.5 & 0.0 \\
\hline Slovak Republic & 0 & 2 & 5 & 8 & .. & 0.0 \\
\hline Spain & 128 & 230 & 337 & 491 & 11.9 & 0.5 \\
\hline Sweden & 870 & 934 & 1573 & 2243 & 8.2 & 2.4 \\
\hline Switzerland & 1760 & 2093 & 2108 & 3023 & 4.6 & 3.2 \\
\hline Turkey & 2 & 3 & 3 & 26 & 23.8 & 0.0 \\
\hline United Kingdom & 3255 & 3200 & 3152 & 4131 & 2.0 & 4.4 \\
\hline United States & 12352 & 17928 & 22233 & 28366 & 7.2 & 30.1 \\
\hline European Union & 22168 & 26353 & 29877 & 42265 & 5.5 & 44.8 \\
\hline OECD & 44773 & 60468 & 68512 & 92356 & 6.2 & 97.9 \\
\hline Total & 45365 & 61272 & 69534 & 94336 & 6.3 & 100.0 \\
\hline
\end{tabular}

Source: OECD, Patent Database, November 2003. 
Table A8. Effective EPO applications as a percentage of "potential EPO applications" (Table A7/Table A6)

\begin{tabular}{l|rrcc}
\hline & 1986 & 1990 & 1995 & $\mathbf{1 9 9 8}$ \\
\hline Australia & 71.4 & 51.7 & 50.5 & 50.6 \\
Austria & 98.3 & 94.7 & 89.0 & 87.9 \\
Belgium & 99.0 & 93.1 & 92.8 & 90.5 \\
Canada & 98.6 & 69.2 & 68.7 & 73.4 \\
Czech Republic & 100.0 & 91.5 & 40.6 & 59.7 \\
Denmark & 82.9 & 73.9 & 73.0 & 79.8 \\
Finland & 85.4 & 73.7 & 78.7 & 78.3 \\
France & 98.3 & 94.0 & 91.8 & 91.1 \\
Germany & 98.4 & 95.2 & 91.1 & 89.9 \\
Greece & 100.0 & 79.5 & 71.9 & 79.9 \\
Hungary & 90.1 & 66.7 & 51.1 & 40.3 \\
Iceland & 80.0 & 100.0 & 60.0 & 47.5 \\
Ireland & 100.0 & 100.0 & 79.3 & 80.7 \\
Italy & 98.0 & 95.6 & 92.2 & 90.1 \\
Japan & 98.5 & 98.3 & 94.1 & 91.8 \\
Korea & 68.4 & 84.9 & 83.2 & 73.9 \\
Luxembourg & 100.0 & 98.1 & 84.6 & 87.8 \\
Mexico & 100.0 & 100.0 & 50.0 & 45.5 \\
Netherlands & 99.5 & 96.1 & 90.4 & 88.1 \\
New Zealand & 100.0 & 82.1 & 40.0 & 43.8 \\
Norway & 85.0 & 65.9 & 67.3 & 64.9 \\
Poland & 100.0 & 55.6 & 42.9 & 42.6 \\
Portugal & 100.0 & 100.0 & 93.5 & 80.9 \\
Slovak Republic &.. & 100.0 & 28.8 & 40.3 \\
Spain & 100.0 & 87.5 & 75.8 & 73.2 \\
Sweden & 84.4 & 77.9 & 79.0 & 76.8 \\
Switzerland & 98.0 & 95.8 & 88.8 & 89.8 \\
Turkey & 100.0 & 100.0 & 52.9 & 55.2 \\
United Kingdom & 95.0 & 81.7 & 78.6 & 78.2 \\
United States & 94.9 & 84.6 & 76.3 & 71.9 \\
European Union & 97.0 & 91.7 & 88.1 & 87.0 \\
OECD & 96.4 & 90.1 & 83.9 & 81.5 \\
Total & 96.4 & 90.0 & 83.6 & 80.9 \\
\hline & & & & \\
\hline
\end{tabular}

Source: OECD, Patent Database, November 2003. 


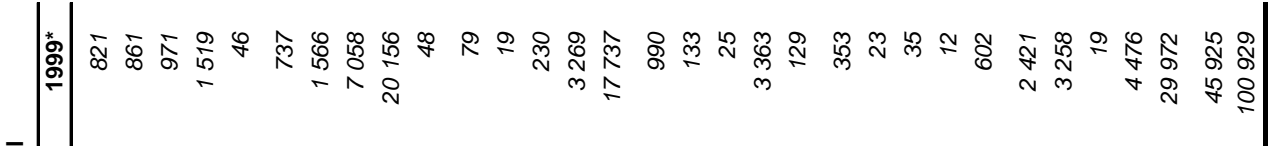

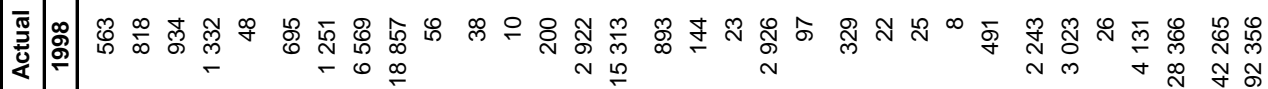

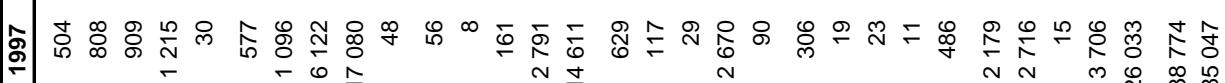

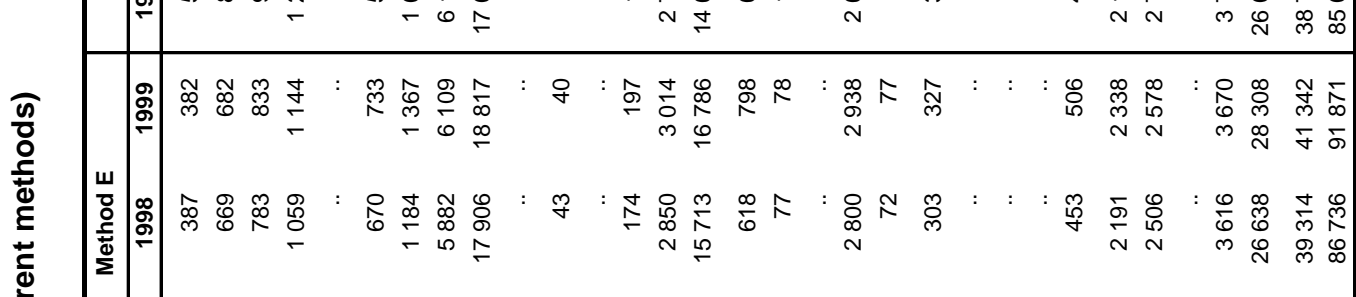

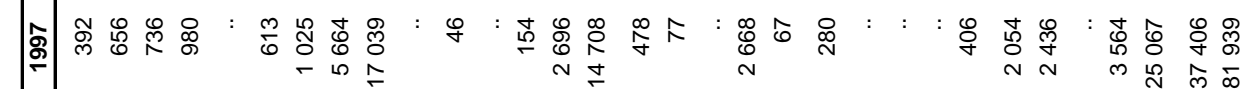

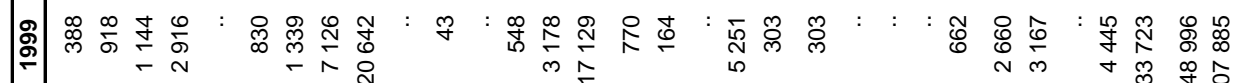

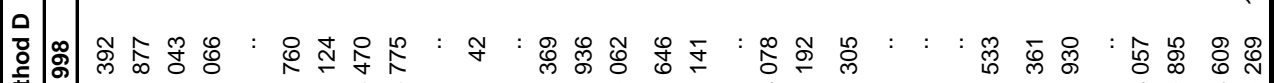

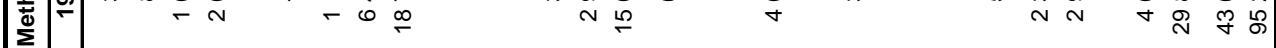

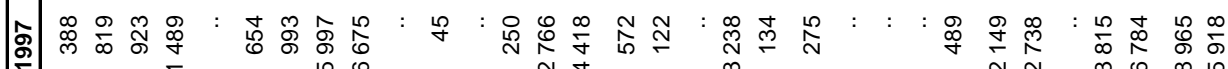

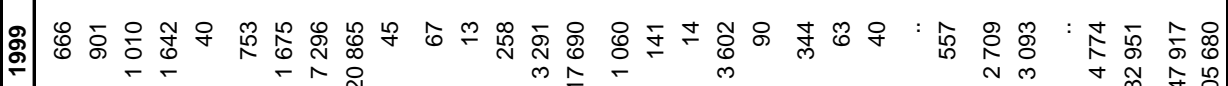
0

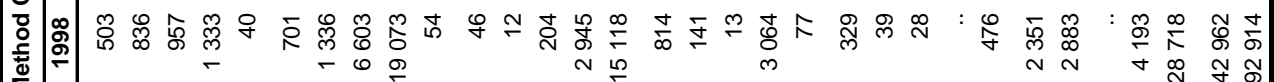
高尊芯荅芯

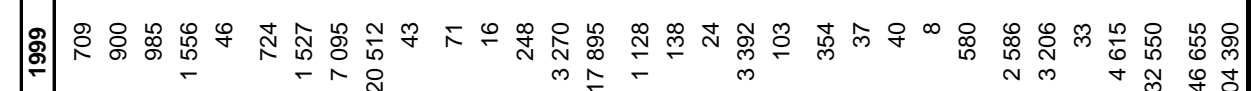

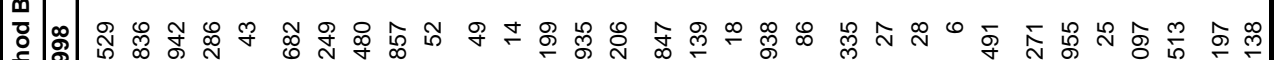

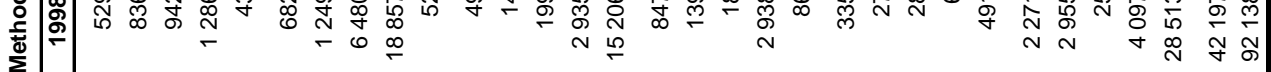

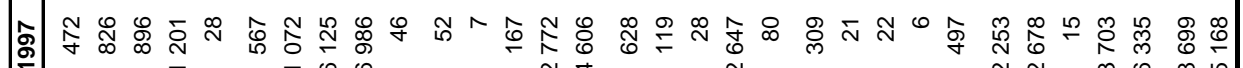

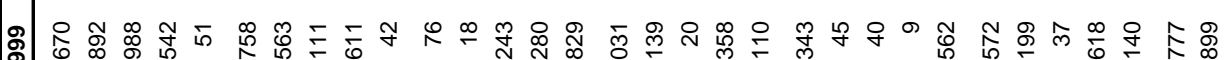

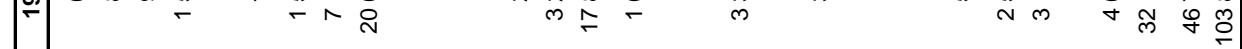
。

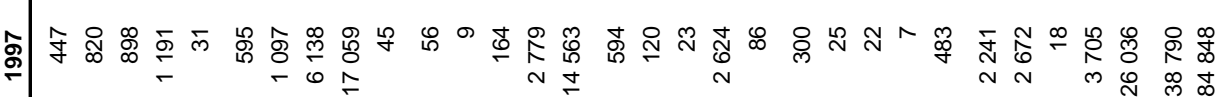

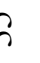




\section{REFERENCES}

Armstrong \& Associates, "International Patent Applications - Patent Cooperation Treaty", www.canpat.com/files/pct.pdf

Akers, N. (1999), “The European Patent System: An Introduction for Patent Searchers", World Patent Information 21 (1999), 135-163.

Brown \& Michaels, "Budget Estimator for Patents", www.bpmlegal.com/patfees.html

Dehon, C. and B. Van Pottelsberghe (2003), "Implementing a Forecasting Methodology for PCT

Applications at WIPO", paper presented at the WIPO-OECD Workshop on Statistics in the Patent Field, Geneva.

EPO, "European Patent Convention", www.european-patent-office.org/legal/epc/index.html

EPO, "EPO Press Releases", various editions, www.european-patent-office.org/news/pressrel/index.htm.

EPO, "How to Get a European Patent: The Guide for Applicants",

www.european-patent-office.org/ap_gd/index.htm

EPO, "EPO Facts and Figures", various editions,

www.european-patent-office.org/epolfacts_figures/index.htm

Grupp, H. and U. Schmoch (1999), "Patent Statistics in the Age of Globalisation: New Legal Procedures, New Analytical Methods, New Economic Interpretation”, Research Policy 28 (1999), 377-396.

Joutz, F. (2003), "Forecasting USPTO Patent Application Filings", paper presented at the WIPO-OECD Workshop on Statistics in the Patent Field, Geneva.

Nicolas, M. and P. Hingley (2003), "Forecasting the Number of European Patent Applications at the European Patent Office", paper presented at the WIPO-OECD Workshop on Statistics in the Patent Field, Geneva.

Schmoch, U., R. Bierhals, and R. Rangnow (1998), "Impact of International Patent Applications on Patent Indicators", report for the OECD.

OECD (2004), "Compendium of Patent Statistics", OECD, Paris, www.oecd.org/sti/ipr-statistics

WIPO, "Yearly Review of the PCT", various editions, www.wipo.int/pct/en/access/news.htm

WIPO, "PCT Newsletter", various editions, www.wipo.int/pct/en/newslett/index.htm

WIPO (2003), “The PCT Applicant's Guide”, WIPO, Geneva.www.wipo.int/pct/guide/en/index.html 